\title{
Influence of natural discontinuities and mechanical properties on the fragmentation of marble by blasting in Central Africa
}

\section{Michel Constant Njock}

University of Yaounde I: Universite de Yaounde I

Jorelle Larissa Meli'i

Université de Yaoundé I: Universite de Yaounde I

Yvonne Koffi Poufone

Institut National de Cartographie

Ibrahim Ngapouth Mbouombouo

Université de Yaoundé l: Universite de Yaounde I

Linda Well Have Tamto

Université de Yaoundé l: Universite de Yaounde I

\section{Zakari Arétouyap}

Université de Dschang: Universite de Dschang

\section{Eliézer Manguelle-Dicoum}

Académie des Sciences du Cameroun

Philippe Nouck Njandjock ( $\nabla$ pnnouck@yahoo.com )

Universite de Yaounde I

\section{Research Article}

Keywords: Natural discontinuity, Mechanical property, Blasting, Fragmentation, Kuz-Ram model, Marble quarry

Posted Date: March 29th, 2021

DOI: https://doi.org/10.21203/rs.3.rs-327042/v1

License: (c) (i) This work is licensed under a Creative Commons Attribution 4.0 International License. Read Full License 


\section{Title: Influence of natural discontinuities and mechanical properties on the fragmentation of marble by blasting in Central Africa}

Michel Constant Njock $^{\mathrm{a}}$, Jorelle Larissa Meli' ${ }^{\mathrm{a}}{ }^{\mathrm{a}}$, Yvonne Koffi Poufone $^{\mathrm{b}}$, Ibrahim Ngapouth Mbouombouo ${ }^{\mathrm{a}}$, Linda Well Have Tamto ${ }^{\mathrm{a}}$, Zakari Arétouyap ${ }^{\mathrm{c}}$, Eliézer Manguelle-Dicoum ${ }^{\mathrm{a}, \mathrm{d}}$, Philippe Njandjock Nouck $^{\mathrm{a} *}$

${ }^{a}$ Department of Physics, University of Yaounde I, Yaounde, Cameroon

${ }^{b}$ Department of Cartography, National Institute of Cartography, Yaounde, Cameroon

${ }^{c}$ Department of Geosciences, University of Dschang, Dschang, Cameroon

${ }^{d}$ Department of Geotechnics, Cameroon Academy of Science, Yaounde, Cameroon

*Corresponding author, E-mail: pnnouck@yahoo.com; Phone: 00237 677661006/

698801270; Address: Ngoa-Ekelle, P.O. Box 812 Yaounde - Cameroon 


\begin{abstract}
This research focuses on the influence of natural discontinuities and mechanical properties in the fragmentation of marble by blasting. These natural discontinuities and mechanical properties are the parameters which are difficult to control and which considerably influence the fragmentation of marble after blasting. This paper aims at predicting the fragmentation of the Bidzar quarry rock, the only marble quarry in Central Africa, while improving the knowledge on it. This quarry has been facing problems of fragmentation of marble blocks for decades, which requires secondary firing and incurs enormous costs. The Kuz-Ram method was used for this study. The dip of the discontinuity planes, the compressive strength, the distance between the discontinuities and the density of the discontinuities are the operational parameters that were used to study the influence of natural discontinuities and the mechanical properties of the rocks on the fragmentation after firing. This work consists precisely in studying the pullability as a function of the dip of the discontinuity planes, then the fragmentation as a function of the powder factor, the compressive strength and the drilling mesh. The results of this study were compared with those of the other authors. Qualitative and quantitative studies were carried out in order to highlight the influence of natural discontinuities and mechanical characteristics on fragmentation. The fragmentation pattern of the Bidzar quarry was examined and compared with those obtained in other regions of the world, namely, Northern Europe, Central America, South-East Asia and West Africa. The variation in the intensity of fragmentation caused on the one hand by differences in the dips of the firing planes and their compressive strength, and on the other hand by the variation in the drilling mesh was also discussed. The prediction test was carried out with seven plans of existing discontinuities in the Bidzar quarry and at different mesh sizes in order to estimate the distribution of the fragments of marble thatcan through the crsuher after being fired. Several suggestions were put forward for the evaluation of the fragmentation. Three practical tables were created to predict the result of the shot. The specific graphs, which were proposed to analyse fragmentation in this quarry, made it possible to assess the quantity of fragments passing through the crusher after firing. Predicting fragmentation by considering the dip of the firing planes and the powder factor can effectively optimise the fragmentation of the rocks by blasting and achieve the desired result.
\end{abstract}

Keyswords: Natural discontinuity, Mechanical property, Blasting, Fragmentation, Kuz-Ram model, Marble quarry 


\section{INTRODUCTION}

The fragmentation of boulders by blasting has always been an important aspect of mining and is the subject of numerous studies (Sang Ho Cho et al, 2004; Gheibie et al, 2009; Stjepan et al, 2011; Biessikirski et al, 2019; Shaib et al, 2020). The size of the fragments obtained should also not exceed the opening of the crushing plant for efficient operation (Jug et al, 2017; Shaib et al, 2020). The presence of large blocks requires secondary fragmentation to further reduce the material pulled to acceptable sizes, thereby increasing production costs (Rustan, 1990; De Lile, 2012; Mohammad et al, 2018; Yahyaoui et al, 2018; Agyei et al, 2019). In general, when blasting, there is not always a match between the size of the blocks shot and the size of the crusher mesh. In addition, knowledge of the properties of the rock matrix is important in modelling a blast. These properties (natural discontinuities and physicomechanical characteristics) are fundamental for the optimisation of fragmentation and constitute the uncontrollable parameters of a blast (Adebayo et al, 2007; Akbari et al, 2015; Jug et al, 2017; Behrouz, 2018).

In recent decades, several researchers have conducted studies on the influence of natural discontinuities and physico-mechanical characteristics on the fragmentation of rocks by blasting. For the influence of geological discontinuities on fragmentation, Hustrulid (1999) and Abu Bakar et al (2013) quoted Burkle (1979) on the fact that blasting results are affected by the orientation of the rock mass structures and three cases are thus considered, dipping blasting, blasting against the dip and blasting along the direction of the dip. Firing on slopes oriented perpendicular to the direction of the main joints results in better fragmentation with smaller rock fragments (Ash, 1973; Singh, 2005). Fragmentation of a rock mass occurs mainly along discontinuities and its intensity is characterised by the distance between fractures, their width and position in the rock mass (Ash, 1973; Fogelsen et al, 1958). Furthermore, the spacing between fractures determines the dimensions of the boulders that will be fragmented and influences the overall stability of the slopes (Devkota et al, 2009). Discontinuity planes considered as firing planes allow the choice of the orientation of the felling front which favours the best fragmentation of the rock, ensures the stability of the front and minimises felling difficulties (Ash, 1973; Abu Bakar et al, 2013; Yahyaoui et al, 2018). The choice of a free felling front that favours rock fragmentation is influenced by the dip of the plane of discontinuity, while the family class of direction to which the plane of discontinuity of firing belongs influences the stability, good alignment and security of the front (Belland, 1968; Yahyaoui et al, 2018). The experiments of Worsey et al (1981) show 
that the shooting results depend on the angle between the designed perimeter line and the discontinuity. If this angle is less than $60^{\circ}$, the results of the explosion will be poor, whereas if the angle is less than $15^{\circ}$, then the explosion will be meaningless compared to a normal explosion.

With regard to the influence of physical-mechanical properties on fragmentation, several studies have demonstrated the important effects of the physical and mechanical properties of rocks on the results of blasting, and these represent the uncontrollable parameters of the blast (Ash, 1973; Adebayo et al, 2007; De Lile, 2012; Mulenga, 2020). Blast fragmentation is influenced by the physical-mechanical properties of the rock mass, including compressive strength, tensile strength, rock density, Poisson's ratio and Young's modulus (De Lile, 2012; Jug et al, 2017). Tensile strength is theoretically the most important mechanical property of the rock mass for mining (De Lile, 2012). Compressive strength, on the other hand, determines the behaviour of the rock in the vicinity of the detonation load (Rustan, 1990). The density of the rock mass is also considered to be an important factor influencing the fragmentation of the rocks caused by the explosion. In general, the ease or difficulty of breaking rock is dictated by the density of the rock (Behrouz, 2018). Variation in density has a significant impact on the performance of the explosion and the fragmentation induced by the explosion (Behrouz, 2018). The significance of the Poisson's coefficient is that rocks with low Poisson's coefficients respond more favourably to blasting efforts (Segaetsho et al, 2019). Young's modulus is commonly used as a measure of rock rigidity and for blasting purposes, as rigid rocks tend to produce higher equalisation energy early in the detonation process (Behrouz, 2018; Segaetsho et al, 2019).

A discontinuity is an inetrruption of rock resulting from the formation of a rock. Indeed, there are the areas of weakness through which the rock will break more easily as a result of high impact energy. A distinction is made between natural and anthropogenic discontinuities. Natural discontinuities are those which have been naturally established either by geological or mechanical phenomena or by other phenomena whereas anthropogenic discontinuities are the discontinuities which have been caused by human activities such as the firing of mine. Stratification joints, tension cracks and fault are exclusively natural origin whereas cracks and fractures can be of natural or provoked origin. The discontinuity in the Bidzar quarry under study are the stratification joints which are the contact zones between the alternating marble and schist layers in a vertical to subvertical dip. 
The aim of this paper is to estimate the distribution of marble boulder fragments that can be crushed, considering the effect of natural discontinuities and mechanical properties using the Kuz-Ram prediction model, while enhancing the information on the Bidzar quarry rock. The Kuz-Ram model is the most widely used prediction method in rock blasting and has the advantage that it combines intrinsic rock properties, explosive properties and design variables (Cunningham 1983, 1987 and 2005; Biessikirskiet al, 2019). This work it is to study, on the one hand, the tirability as a function of the dip of the firing planes, then the fragmentation as a function of the powder factor, the compressive strength and the drilling mesh.

Consequently, an in-depth study was carried out to show the influence of natural discontinuities and mechanical properties on the fragmentation of rocks by blasting. In the following pages, the materials are first discussed, the data collection site is described, the relationship between the discontinuities, the mechanical parameters and the consumption of explosives is discussed. The next part explains in detail with equations the Kuz-Ram prediction method, followed by the results and the discussion. Finally, the conclusion section gives a brief summary of the findings.

\section{MATERIALS AND METHOD}

\section{MATERIALS}

\section{Description of the study area and the site measurements}

The Bidzar quarry is located by the geographical coordinates $09^{\circ} 55^{\prime}$ and $09^{\circ} 56^{\prime}$ North longitude, $14^{\circ} 07^{\prime} 13^{\prime \prime}$ and $14^{\circ} 07^{\prime} 68^{\prime \prime}$ East latitude (Fig.1), and is situated in the Region of North Cameroon, Department of Mayo-Louti, $25 \mathrm{~km}$ north of the district of Figuil, more precisely in the locality of Bidzar, on a hill with an average altitude of $450 \mathrm{~m}$ (Wouatong et al, 2017). The Bidzar quarry is a marble deposit located in Central Africa between Nigeria, Chad, Central African Republic and Cameroon. This marble is used not only in the manufacture of cement but also for decoration. The annual production of the quarry varies between 1.100 .000 and 250.000 tons per year.

The rock of the Bidzar quarry is a deposit of metamorphic type whose rock exploited is marble. This marble alternates in some places with the schist layers in a vertical dip and other types of rock such as dolomite, talc, granite and gneiss can be found in the quarry. There are three varieties of marble in the quarry, white, pink and black coloured marble. But the majority of the marble is white. The layers of marble and shale in this quarry have a major northward direction and dip subvertically to vertically. Joints, fractures, folds and lineations 
easily observable. In fact, this marble deposit originates from a varied volcano-sedimentary phenomenon that prevailed in the Bidzar area and whose main tectonic imprint is the $D_{2}$ deformation phase, characterised by a high degree of metamorphism that led to the transformation of clay into shale, limestone into marble and quartz sandstone into green shale (Wouatong et al, 2017). The tectonic history of the area is characterised by two deformation phases that developed in the Neoproterozoic (Ndjeng,1998). The $\mathrm{D}_{1}$ deformation phase, which is globally NNE-SSW to N-S and the $\mathrm{D}_{2}$ deformation phase, considered as the major deformation phase, is globally NE-SW with a subvertical dip. These two deformation phases are responsible for the multiple fractures that exist in the Bidzar zone and its surroundings giving several fracture directions N-S, NE-SW, NNE-SSW, ENE-WSW, ESE-WNW, NNWSSE (Ndjeng, 1998). The physical and mechanical characteristics of Bidzar marble are given as follow, harness 3 , an absolute density $2.77 \mathrm{~g} / \mathrm{m}^{3}$, a bulk density $2.75 \mathrm{~g} / \mathrm{m}^{3}$, mechanical fragmentation strength $32 \%$ to $31 \%$, wear strength $33 \%$ and $25 \%$ respectively for the granular classes $6 / 10 \mathrm{~mm}$ and 10/14 mm, simple compression strength $75 \mathrm{MPa}$ and an indirect tensile strength 8.9 MPa (Wouatong et al, 2017). The Young's modulus is of $106 \mathrm{Mpa}$. The Poisson's coefficient is 0.28 .

Two types of explosives were used in the Bidzar quarry, the Explus TSR type cartridge and the Anfo type bulk explosive. The type of firing used was electric and the meshes used in the quarry were $3 \mathrm{~m} \times 3 \mathrm{~m}, 4 \mathrm{~m} \times 4 \mathrm{~m}, 4.5 \mathrm{~m} \times 4.5 \mathrm{~m}$. Seven discontinuity planes (or firing planes) taken in the field, of direction and dip N08E86, N20E70, N40E85, N56E75, N80E60, N120E90, N156E82 and respective compressive strength, 74 Mpa, 86.8 Mpa, 75 Mpa, 82.8 Mpa, 94.7 Mpa, 71 Mpa, 75.6 Mpa, are used to predict fragmentation using the deKuz-Ram model. The holes are drilled with a diameter of $115 \mathrm{~mm}$, an inclination of $5^{\circ}$ to the vertical and the depth of the holes is $10 \mathrm{~m}$. The overdrilling depth is $1 \mathrm{~m}$ with a final head packing at $2 \mathrm{~m}$. Eleven measuring lines, $12 \mathrm{~m}$ long, were taken on the platform to be shot for each shot, where the spacing and number of fractures and discontinuity planes were measured, this made it possible to calculate the parameters including the linear density of the discontinuities and the average spacing between the discontinuities (Table 1). Linear density and mean spacing between discontinuities are given by Porokhovoi's (1995) formula according to equations (1) and (2). The RQD (Rock Quality Design) which is the first index for the evaluation of billing from core analysis and developed by Priest and Hudson (Porokhovoi, 1995) is given by the formula (eq.3).

$$
\mathrm{D}=\mathrm{N} / \mathrm{L}
$$


D: linear fracture density (fracture/m), N: number of fractures intersected by the measurement line, L: length of measurement line (m)

$$
\mathrm{E}=\mathrm{d} / \mathrm{n}
$$

E: mean spacing between fractures $(\mathrm{m}), \mathrm{d}$ : sum of distances between the successive fractures on a measurement line (m), n: number of distances between fractures.

$$
\mathrm{RQD}=\left(\sum_{i=1}^{n} \mathrm{xi} / \mathrm{L}\right) \times 100
$$

RQD: rock quality design (\%), xi: the length of the ith segment free of fractures and greater than $0.1 \mathrm{~m}(\mathrm{~m}), \mathrm{L}$ : total length $\mathrm{d}$ of the sampling line on which the RQD is calculated $(\mathrm{m}), \mathrm{n}$ : number of fractures intersected by the measurement of the sampling line.

\section{Relationship between discontinuities, mechanical properties and explosive consumption}

The consumption of explosives, on which the total energy reserve of the charge depends, is a factor that influences the quality of rock fragmentation (Ash, 1973; Kamoulete, 2014; Singh, 2015). Djoudi et al (1997) even believe that with variation in the specific explosive consumption, it is possible to have the expected fragmentation. The influence of discontinuities on the degree of fragmentation of a rock is characterised by the distance between the cracks, their width and their place in the rock (Fogelsen et al, 1958). The academician Ashby developed an empirical formula between the specific consumption of explosive, the properties of the rock including the frequency of fractures and the shear strength (Ash, 1973) expressed in equation (4). Table 1 shows the data for the average fracture frequencies collected in the field and the resulting specific consumption of explosive as a function of the rock parameters, and allows the Ash curve to be plotted.

$$
Q_{\text {exp }, \text { Anfo }}=1.4 \tan (\varnothing+i) / \sqrt[3]{\text { fracture } / \text { meter }}
$$

Qexp, Anfo: specific explosive consumption in Anfo $\left(\mathrm{kg} / \mathrm{m}^{3}\right), \emptyset$ : angle of internal friction of the rock $\left(^{\circ}\right)$, i: roughness angle of the fracture surfaces.

The angle of friction (eq.5) is given by the relation (M'zonchem et al, 2006):

$$
\emptyset=\arcsin \left(\left(R_{c}-4 R_{t}\right) /\left(R_{c}-2 R_{t}\right)\right)
$$

The contact surface between the rock blocks being rough flat surfaces is evaluated by the roughness angle of the fracture surfaces (eq.6) given by the following equation (Metftah, 2010):

$$
i=\varnothing / 3
$$


$\emptyset$ : angle of friction $\left(^{\circ}\right)$, i: roughness angle of the fracture surfaces, Rc: compressive strength (MPa), Rt: tensile strength (MPa).

\section{METHOD}

The Kuz-Ram model is the most widely used approach for predicting rock fragmentation by blasting and has the advantage that it combines rock properties such as natural discontinuities and physical-mechanical characteristics, explosive properties and design variables (Cunningham 1983, 1987 and 2005; Biessikirski et al, 2019). This model has three key equations, the Kuznetsov equation (1973), the Rosin-Rammler equation (1973) and the Cunningham equation (1983, 1987 and 2005) as indicated in the equations (eq.7, 15, 16). The average fragment size that $50 \%$ of the material passing through the crusher is given by Kuznetsov's equation (eq.7).

$$
\mathrm{X}_{\mathrm{m}}=\mathrm{A} \times\left(\frac{\mathrm{V}}{\mathrm{Q}_{\mathrm{e}}}\right)^{0.8} \times \mathrm{Q}^{0.167}
$$

$\mathrm{Xm}$ : the mean size of fragment that $50 \%$ of materials passing $(\mathrm{cm}), \mathrm{A}$ : rock factor, $\mathrm{V}$ : the rock volume broken per blast hole $\left(\mathrm{m}^{3}\right), \mathrm{Q}_{\mathrm{e}}$ : mass of explosive in the blast hole $(\mathrm{kg})$.

$\mathrm{K}$ is the powder factor or specific charge (Adebola et al, 2016). It is the mass of explosives being used to break a cubic meter's volume. The powder factor can be determined by Equation (8) as presented by (Gadikor, 2018).

$$
\mathrm{K}=\mathrm{Q}_{\mathrm{e}} / \mathrm{V}
$$

$\mathrm{K}$ : powder factor $\left(\mathrm{kg} / \mathrm{m}^{3}\right), \mathrm{Q}_{\mathrm{e}}$ : mass of explosive in the blast hole $(\mathrm{kg}), \mathrm{V}$ : rock volume broken per blast hole $\left(\mathrm{m}^{3}\right)$.

$\mathrm{K}$ (specific charge) also depends on several parameters, including the crack of the rock, the volume of blown rock, the explosive charge and the degree of rock fragmentation (Belhous, 2016). It is also given by the formula (eq.9).

$$
\mathrm{K}=\text { qet } \times \text { Kex } \times \text { Kfiss } \times \mathrm{Kd} \times \mathrm{Kc} \times \mathrm{Kv} \times \mathrm{Ksd}
$$

$\mathrm{K}$ : specific charge $\left(\mathrm{kg} / \mathrm{m}^{3}\right)$, qet: rock pullability $\left(\mathrm{g} / \mathrm{m}^{3}\right)$, Kex: transformation index of the standard explosive, Kfiss: cracked index which considering the cracking of the mass , Kv: index which considering the influence of the volume of blasted rock for the steps, Kd: index which considering the degree of fragmentation, Kc: index which considering the degree of real concentration of the load, Ksd: index which considering of the arrangement of the load and the surface number of the mass attracted by case in two free surfaces. 
The pullabilty of the rock makes it possible to characterize the degree of this one. It varies according to the mechanical properties of the rock and the dip of the planes of discontinuities. It is given by the equations (10), (11), (12) and (13) (Belhous, 2016):

$$
\begin{gathered}
\text { qet }=0.02 \times(\sigma \mathrm{c}+\sigma \operatorname{tr}+\tau)+2 \rho \\
\sigma \mathrm{c}=100 \times \mathrm{f} \\
\sigma \operatorname{tr}=0.33 \times \sigma \mathrm{c} \\
\tau=\sigma \mathrm{c} / 10
\end{gathered}
$$

qet: pullability of the rock $\left(\mathrm{g} / \mathrm{m}^{3}\right)$, $\sigma \mathrm{c}$ : resistance of the rock to simple compression $\left(\mathrm{kgf} / \mathrm{cm}^{2}\right)$, $\sigma \mathrm{tr}$ : resistance of the rock to traction $\left(\mathrm{kgf} / \mathrm{cm}^{2}\right), \tau$ : resistance of the rock to shear $\left(\mathrm{kgf} / \mathrm{cm}^{2}\right), \rho$ : shear strength $\left(\mathrm{kgf} / \mathrm{cm}^{2}\right)$, f: slope hardness ratio.

Cunningham (2005) stated that the evaluation of rock factors for blasting should at least consider the density, mechanical strength, elastic properties and structure (Table 3). The equation of Rock factor is by the equation formula (eq.14):

$$
\mathrm{A}=0.06 \times(\mathrm{RMD}+\mathrm{JF}+\mathrm{RDI}+\mathrm{HF})
$$

A: rock factor, RMD: rock mass properties, JF: joint factor; RDI: rock density, HF: hardness factor

The distribution (Rosin et al, 1933) was used to evaluate the proportion of particles passing through a specific screen size as given in following equation (eq.15).

$$
P(X)=100 \times\left(1-\exp \left(-\left(\frac{X}{X_{c}}\right)^{n}\right)\right.
$$

$\mathrm{P}(\mathrm{X})$ represents the percentage of material that will pass through a screen of a particular mesh size $(\%), \mathrm{n}$ is the uniformity index, $\mathrm{Xc}$ is the characteristic size that $63.2 \%$ of materials passing $(\mathrm{cm})$ and $\mathrm{X}$ is the particle size $(\mathrm{cm})$.

Equation (16) further established by Cunningham (1987) was used to calculate the uniformity index (n) by incorporating the effects of blast geometry:

$$
\mathrm{n}=\left(2.2-14\left(\frac{\mathrm{B}}{\mathrm{D}}\right)\right) \times\left(1-\left(\frac{\mathrm{W}}{\mathrm{B}}\right)\right) \times\left(\left(1+\left(\frac{\mathrm{E}}{\mathrm{B}}\right)\right) / 2\right)^{0.5} \times\left(\frac{\mathrm{L}}{\mathrm{H}}\right)
$$

Where $\mathrm{n}$ is uniformity index, $\mathrm{B}$ is the bench (m), $\mathrm{E}$ is the spacing $(\mathrm{m}), \mathrm{D}$ is the hole diameter $(\mathrm{mm}), \mathrm{W}$ is the standard deviation of drilling accuracy $(\mathrm{m}), \mathrm{L}$ is the length of charging $(\mathrm{m})$ and $\mathrm{H}$ is the bench height $(\mathrm{m})$. 
The standard deviation of drilling accuracy is given by the equation (17) (Gaucher, 2011):

$$
\mathrm{W}=\mathrm{D} / 1000+(0.03 \times \mathrm{Lt})
$$

W: Borehole deviation (m), D: diameter of hole (mm), Lt: total length of hole of the hole (m).

And the total length of hole is given by the formula in equations (18) and (19) (Gaucher, 2011):

$$
\begin{aligned}
& \mathrm{Lt}=\frac{\mathrm{H}}{\cos \mu}+\mathrm{Ls} \\
& \mathrm{Ls}=0.3 \times \mathrm{Bth}
\end{aligned}
$$

Lt: total length of hole of the hole (m), Ls: overdrilling of hole (m), Bth: theoretical bench (m), H: height of the step (m), $\mu$ : angle of inclination of the hole relative to the vertical $\left(^{\circ}\right)$.

The formula for the theoretical bench is given by the empirical relation of Langefors et al (1979) in equations (20), (21) and (22):

$$
\text { Bth }=1.08 \times \sqrt{(\operatorname{Lf} \times S)} /\left(\operatorname{Cin} \times \operatorname{Rt} \times\left(\frac{E}{B}\right)\right)
$$

Bth: theoretical bench (m), Rt: resistance to pulling, E/B: mesh ratio, W: borehole deviation (m), Cin: stress factor, S: energy coefficient; Lf: linear load $(\mathrm{kg} / \mathrm{m})$.

$$
\mathrm{S}=\mathrm{Q} / \mathrm{Qo}
$$

S: energy coefficient, Q: explosive energy of Explus (MJ/kg), $\mathrm{Q}_{0}$ : explosive energy of Anfo $(\mathrm{MJ} / \mathrm{kg})$.

$$
\mathrm{Lf}=\pi \times \mathrm{d} \times\left(\frac{\phi 2}{4}\right) \times \mathrm{Kt}
$$

Lf: linear load $(\mathrm{kg} / \mathrm{m})$, d: density of the explosive (Explus and Anfo) used $\left(\mathrm{g} / \mathrm{m}^{3}\right)$ et $\phi$ : diameter of the explosive (Explus and Anfo) used (mm), Kt: explosive settlement coefficient.

By using Rosin and Rammler equation (15), the characteristic size Xc is calculated from the average size by substituting $\mathrm{X}=\mathrm{Xm}$, and $\mathrm{y}=0.5$ into equation (15) which results into equation (23) below:

$$
\mathrm{X}_{\mathrm{c}}=\mathrm{X}_{\mathrm{m}} /(0.693)^{1 / \mathrm{n}}
$$

$\mathrm{Xc}$ is the characteristic size of particle that $63.2 \%$ of materials passing $(\mathrm{cm}), \mathrm{Xm}$ is the mean size of particles that $50 \%$ of materials passing $(\mathrm{cm})$ and $\mathrm{n}$ is the uniformity index. 


\section{RESULTS AND DISCUSSION}

\section{Rock quality}

The simple compressive strength of Bidzar marble is $75 \mathrm{MPa}$, indicating that it is a medium-hard, class II and grade $\mathrm{R}_{4}$ (Porokhvoi, 1995; Sing et al, 2007; Gadikor, 2018). The RQD of the Bidzar quarry rock is $93 \%$, showing that this marble is of excellent quality and class RQD 1 (Aftes, 2001). The rock factor is about 10.455, confirming that the rock is hard and moderately cracked (Ouchterlony et al, 2019). The average spacing between fractures is $1.08 \mathrm{~m}$ and the average spacing between planes of discontinuities is $80.53 \mathrm{~cm}$ (Table 2), showing that the Bidzar rock is of class ES2 and the discontinuities are spaced (Aftes, 2001). The average density of the fractures is $1.02 \mathrm{~m}^{-1}$ and the average density of the planes of discontinuities is $1.60 \mathrm{~m}^{-1}$ (Table 2), showing that the Bidzar marble is of class ID2 and of low discontinuity density (Aftes, 2001). Therefore, the rocky of the Bidzar quarry is moderately fissured. The strong fracturing of the marble currently observed in the quarry would be mainly due to the different blasting operations carried out over decades of exploitation.

\section{Discontinuity plans}

Major, secondary and minority management families are classified in terms of frequency respectively, greater than or equal to $10 \%$, between $10 \%$ and $5 \%$ and less than $5 \%$ (Koudou et al, 2014). Fig. 2 shows three families of discontinuity direction in the Bidzar quarry, the major directions (N30-40E, N40-50E, N160-170E), the secondary directions (N10-20E, N50-60E), N80-90E, N140-150E, N150-160E, N170-180E) and minority ones (N00-10E, N20-30E, N40-50E, N70-80E, N100-110E, N110-120E, N120-130E, N130-140E) with a dip of about $85^{\circ}$. This hierarchy of direction families corresponds to the one described by Ndjeng (1998) and Wouatong (2017), translating that the Bidzar rock mass is fractured, a fracturing acquired both naturally during the volcano-sedimentary process that prevailed in the Bidzar area and also artificially by the multiple blasting operations carried out over decades of exploitation. These discontinuity planes can be used as firing planes and influence the fragmentation of the rocks through two parameters, dip and compressive strength. These two parameters, respectively, influence the pulverability and the powder factor. Fig.2.a and fig.2.b show the concentration of discontinuity poles and major discontinuity planes on the stereonet in 2D and 3D, fig.2.c gives the hierarchy of discontinuity planes on the directional rosette and fig.2.d shows the frequency histogram of discontinuity planes in number. Fig.2. b. shows three planes, the N028E69 plane with a westward dip direction (yellow in fig.2.b), the N066E86 plane (blue in fig.2.b) with a dip direction towards NNW and the N289E88 plane (brown in fig.2.b) with a dip direction towards SSW. The quarry planes which are dipping in a 
westerly direction have a lower dip compared to the other planes, and are therefore favourable for producing optimal fragmentation after firing. This is the case, for example, of the N028E69 quarry plan which dips westward, with a relatively low dip in relation to the N066E86 and N289E88 plans (fig.2.a, fig.2.b), will produce a higher fragmentation in relation to the N066E86 and N289E88 plans. For efficient exploitation of the marble from the Bidzar quarry, the western zone would be the ideal area to produce effective fragmentation after blasting, as the firing planes that hang in this area would generate the best productivity.

\section{Discontinuities, Mechanical Properties and Explosive Consumption}

Fig.3 shows the influence of discontinuities and mechanical properties on the consumption of explosives. The shape of the curve showing the evolution of the specific consumption of explosive in Anfo as a function of fracture frequency is decreasing. This curve varies in the same direction as that of Ash (1973) and shows that the consumption of explosive in Anfo decreases as the frequency of fractures increases (Fig. 4). This can be explained by the fact that the discontinuities generate a wave reflection leading to a concentration of stresses in the fractured zone which act in conjunction with those created by the explosive charge, resulting in a reduction in the consumption of explosive to achieve better fragmentation. Equations (2) and (3) give for the Bidzar marble the internal friction angle $49.54^{\circ}$ and the roughness angle $16.51^{\circ}$, showing that the planes of discontinuity are not very rough and the internal friction is low. In the Bidzar quarry, as the fractures and planes of discontinuity are spaced (more than $1 \mathrm{~m}$ apart for fractures and more than $80 \mathrm{~cm}$ for planes of discontinuity), it will be necessary to concentrate a large quantity of explosive charge in order to have the best possible fragmentation.

\section{Pullability and dip of the planes of discontinuity}

Among the quarry discontinuity plans, some may correspond to the firing plan while others may not be firing plans. Table 4 to 6 shows that discontinuity plans with a dip greater than $60^{\circ}$ are difficult to shoot, while discontinuity plans with a dip less than or equal to $60^{\circ}$ are very difficult according to the classification table of tirabilities (Saadoun, 2012). With the exception of the $60^{\circ}$ dip firing plane, which is very difficult to fire and equal to $32.056 \mathrm{~g} / \mathrm{m} 3$, planes with a dip discontinuity greater than or equal to $60^{\circ}$ and with a tirability less than or equal to $32.056 \mathrm{~g} / \mathrm{m}^{3}$ are subvertical to vertical planes, and can be used as a firing plane, whereas planes with a dip discontinuity of less than $60^{\circ}$ and with a drawability of more than $32.056 \mathrm{~g} / \mathrm{m}^{3}$ are subhorizontal to horizontal planes, and cannot be firing planes. This result is in line with the work of Worsey et al (1981), which shows that if the dip of the discontinuity planes is less than $60^{\circ}$, the results of the blast will be poor. The pullability of the firing planes 
increases with decreasing dip (Table 4 to 6). The dip of the quarry's rock is about $85^{\circ}$ and of average tirability $26,540 \mathrm{~g} / \mathrm{m}^{3}$, showing that the Bidzar marble is of difficult tirability, class 3 and categories 11, 12, 13, 14 (Saadoun, 2012).

\section{Powder factor, compressive strength and fragmentation resistance}

Table 4 to 6 shows that the compressive strength is a function of the dip of the firing planes and the slope hardness of the front to be fired. This compressive strength varies in the same direction as the slope hardness and increases with decreasing dip. The dip of the planes and the slope hardness are two dependent parameters that vary in opposite directions. Table 4 to 6 also shows that the uniformity index varies between 1.209 and 1.238, in accordance with De Lile (2012)'s condition that it should be between 0.8 and 2.2. It is 1.238 for the $3 \mathrm{~m} \times 3 \mathrm{~m}$ drilling mesh, 1.209 for the $4 \mathrm{~m} \times 4 \mathrm{~m}$ drilling mesh and 1.183 for the $4.5 \mathrm{~m} \times 4.5 \mathrm{~m}$ drilling mesh, reflecting that the distribution of block size after shooting in the bidzar quarry is uniform.

Table 4 to 6 also shows that the powder factor is between $0.522 \mathrm{~kg} / \mathrm{m}^{3}$ and 0.658 $\mathrm{kg} / \mathrm{m}^{3}$, which is comparable to that of igneous rocks according to Gadikor (2018), and corresponds to the one where rock fracture is difficult (U.S. Bureau of Reclamation, 2001), translating that more explosive should be used during blasting to have effective fragmentation. The powder factors for the Bidzar quarry (Table 4 to 6) are consistent with the recommendations of Choudhary and Sonu (Ninepence et al, 2016) for medium-strength rocks. This table also establishes that, as the average block size decreases with increasing powder factor, this is consistent with the studies of Gadikor (2018). Table 4 to 6 also shows that fragmentation increases with the increase in the powder factor, as does explosive consumption. In other words, the increase in the powder factor leads to an increase in the explosive charge, and consequently to an increase in productivity. This result is in line with studies by Segaetsho et al (2019) showing that the calibration of the explosion occurs towards the hardest rock, increasing the potential for damage to sections of the perimeter. The shot pattern producing optimal fragmentation is the one with the highest powder factor. Table 4 to 6 show that the powder factor does not depend on the drilling mesh, a result that is consistent with the work of Adebola et al (2016) and (Blair, 2015) which states that the powder factor is not an integral part of the mesh design process and therefore does not depend on the drilling mesh.

Table 4 to 6 also show that the compressive strength of the shot pattern has a significant influence on the powder factor, explosive consumption and therefore fragmentation. Indeed, the increase in the compressive strength of the firing plane increases 
the powder factor and the consumption of explosive, which leads to an increase in the intensity of fragmentation (Table 4 to 6). These results are consistent with the work (Blair, 2015), which states that as the free felling face becomes resistant, the powder factor increases, and those of Mulenga (2020), which show that compressive strength has an impact on the performance of the shoot, the quality of fragmentation, and dictates the explosive consumption of the rock to be fired. Table 4 to 6 shows that the dipping firing planes $\left(86^{\circ}\right.$, $75^{\circ}, 90^{\circ}, 82^{\circ}$ ) have a compressive strength between $8 \mathrm{Mpa}$ and $80 \mathrm{Mpa}$ and correspond to semi-hard fronts, whereas the dipping firing planes $\left(70^{\circ}, 75^{\circ}, 60^{\circ}\right)$ have a compressive strength greater than $80 \mathrm{Mpa}$, indicating that they are hard fronts (Porokhvoi, 1995). The result is that firing planes with hard fronts give a higher powder factor and generate the best fragmentation after firing, which is the opposite for firing planes with semi-hard fronts. The firing plane with a $60^{\circ}$ dip and maximum compressive strength of $94.7 \mathrm{MPa}$, has a maximum powder factor of $0.658 \mathrm{~kg} / \mathrm{m}^{3}$, and produces optimum yields at different mesh sizes, $71.78 \%$ at $3 \mathrm{~m} \times 3 \mathrm{~m}$ mesh, $67.85 \%$ at $4 \mathrm{~m} \times 4 \mathrm{~m}$ mesh, $66.46 \%$ at $4.5 \mathrm{~m} \times 4.5 \mathrm{~m}$ mesh (Table 4 to 6 ). The simple compressive strength of the Bidzar rock is $75 \mathrm{Mpa}$ and $85^{\circ}$ dip, which means that Bidzar marble is hard and resistant, therefore it requires a high explosive energy to have an effective fragmentation.

\section{Dip of the firing planes, drilling mesh and fragmentation}

In the Bidzar quarry, the recommendation about the size of mean fragment $(\mathrm{Xm})$ is that this must be between $150 \mathrm{~mm}$ and $550 \mathrm{~mm}$ and the crusher gape is $550 \mathrm{~mm}$. The maximum of block size that can pass through the Bidzar crusher is $550 \mathrm{~mm}$. Fig. 4 to 6 give the percentage of blocks that can pass through the Bidzar crusher for different firing planes of N08E86, N20E70, N40E85, N56E75, N80E60, N120E90, N156E82 and of variable mesh size $3 \mathrm{~m} \times 3 \mathrm{~m}, 4 \mathrm{~m} \times 4 \mathrm{~m}, 4.5 \mathrm{~m} \times 4.5 \mathrm{~m}$ and also show that the productivity varies between $60.08 \%$ and $71.78 \%$. Firing with the $3 \mathrm{~m} \times 3 \mathrm{~m}$ drilling mesh according to the $86^{\circ}, 70^{\circ}, 85^{\circ}$, $75^{\circ}, 60^{\circ}, 90^{\circ}, 82^{\circ}$ dip firing planes gives a Rosin-Rammler slope (X/Xc) greater than 1 (Table 4 to 6), showing a high level of fragmentation with the production of a greater quantity of smaller blocks. Firing with the $4 \mathrm{~m} \times 4 \mathrm{~m}$ mesh gives Rosin-Rammler slopes $(\mathrm{X} / \mathrm{Xc})$ greater than 1 for the dipping firing planes $\left(70^{\circ}, 75^{\circ}, 60^{\circ}, 82^{\circ}\right)$ and less than 1 for the dipping firing planes $\left(86^{\circ}, 85^{\circ}, 90^{\circ}\right.$ ) (Table 4 to 6 ), showing that the level of fragmentation of the dipping firing planes $\left(86^{\circ}, 85^{\circ}, 90^{\circ}\right)$ is low compared to the dipping firing planes $\left(70^{\circ}, 75^{\circ}, 60^{\circ}, 82^{\circ}\right)$. Firing with the $4.5 \mathrm{~m} \times 4.5 \mathrm{~m}$ drilling mesh results in Rosin-Rammler slopes $(\mathrm{X} / \mathrm{Xc})$ greater than 1 for dipping firing planes $\left(70^{\circ}, 75^{\circ}, 60^{\circ}\right)$ and less than 1 for dipping firing planes $\left(86^{\circ}\right.$, $85^{\circ}, 90^{\circ}, 82^{\circ}$ ) (Table 4 to 6 ). These results show that the Rosin-Rammler slope (X/Xc) 
increases as the dip of the firing planes and the drilling mesh decreases. Then the slopes of Rosin-Rammler allow not only to observe the variation of the curves of distribution of de Rosin-Rammler but also to deduce on the fragmentation level.

Fig. 7 to 9 show the distribution curves of de Rosin-Rammler. They represent the fragmentation curve and describe the distribution of the size of the fragments after blasting as a function of the dips of the firing planes and the drilling grid. For a good visibility of the dispersion of the fragmentation curves after blasting, the blasting planes of dip $\left(75^{\circ}, 60^{\circ}, 90^{\circ}\right.$, $82^{\circ}$ ) have been chosen. This choice is justified by the fact the shooting planes of dip and slope of Rosin-Rammler close have almost identical fragmentation curve. They are shooting planes of $\operatorname{dip}\left(86^{\circ}, 85^{\circ}, 82^{\circ}\right)$ on the one hand and dip of $\left(70^{\circ}, 75^{\circ}\right)$ on the other hand. The shooting planes of dip $\left(86^{\circ}, 85^{\circ}\right)$ have almost similar dip and slope of Rosin-Rammler and are closer to the blasting plane of dip $90^{\circ}$ compared to the shooting plane of dip $82^{\circ}$ (Table 4 to 6 ), thus for better observation of the dispersion of the fragmentation curves the shooting plane of dip $82^{\circ}$ is retained. Same observation is made with the shooting planes of $\operatorname{dip}\left(70^{\circ}, 75^{\circ}\right)$. The shooting plane of dip $70^{\circ}$ has a dip and slope of Rosin-Rammler closer to the shooting plane of dip $60^{\circ}$ compared to the shooting plane $75^{\circ}$ (Table 4 to 6 ), then the choice is made on the shooting plane of dip $75^{\circ}$ for better observation of the dispersion of the fragmentation curves. Fig. 7 to 9 also show that the greater the Rosin-Rammler slope, the greater the efficiency of the blocks passing through the crusher, and the higher the Rosin-Rammler curve. Table 4 to 6 also show that the Rosin-Rammler slopes vary between 0.930 and 1.209 for different steering and dipping planes N08E86, N20E70, N40E85, N56E75, N80E60, N120E90, N156E82 and the feed mesh. In this quarry, the firing plane producing optimal block yield after firing is the $60^{\circ}$ dip discontinuity plane at the $3 \mathrm{~m} \times 3 \mathrm{~m}$ mesh, with a Rosin-Rammler slope of 1,209 (Table 4 to 6$)$.

Table 4 to 6 also establish that the fragmentation of a block by blasting depends on the dip of the firing planes, the compressive strength, the powder factor, the amount of explosive and the drilling mesh. Indeed, for the same borehole, the productivity of the blocks passing through the crusher increases when the dip of the firing planes and the drilling mesh decreases and when the quantity of explosive, the powder factor and the compressive strength increase (Table 4 to 6). In addition, for the same borehole, the quantity of explosive increases with the increase in the drilling mesh (Table 4 to 6), and the powder factor increases with the increase in compressive strength (Table 4 to 6). The decrease in the dip leads to an increase in the compressive strength of the blast pattern and the hardness of the slope, resulting in an 
increase in the explosive charge and the powder factor of the face to be shot, thus reducing the average block size and consequently increasing productivity (Table 4 to 6). These results are in line with the work of Singh et al (2015) and Adebola et al (2016), concerning the reduction in block size with the reduction in the drilling mesh, and with the work of Belland (1968), Worsey et al (1981) and Yahyaoui et al (2018), according to which the dip of the main joint planes has a considerable influence on fragmentation. Table 4 to 6 and Fig. 7 to 9 clearly show that the direction of the blast planes does not influence rock fragmentation, but rather the dip of the blast planes influences fragmentation after blasting. This result is cited in the work of Belland (1968) and Yahyaoui et al (2018). On the other hand, the direction of the firing planes has an impact on stability, the correct alignment of the front and the difficulties of felling. This result is in line with those of Ash (1973), Abu Bakar et al (2013) and Yahyaoui et al (2018).

Table 4 to 6 show that fragmentation after firing in the Bidzar quarry gives a productivity less than $80 \%$, indicating that fragmentation is low because, the requirements of the mining companies estimate that for satisfactory blasting producing an excellent fragmentation, at least $80 \%$ of the blocks must pass through the crusher (Ninepence, 2016). The model of the Bidzar illustrated fragmentation curves shown in Fig.7 to 9 shows that $100 \%$ of the blocks pass through the $250 \mathrm{~cm}$ mesh crusher with the drilling diameter $115 \mathrm{~mm}$ (Fig.7 to 9). This compares with models obtained in other regions of the world, notably in Northern Europe, Central America, South-East Asia and West Africa. Thus, Biessikirski et al (2019) predicts $96.38 \%$ and $99.98 \%$ respectively of passers in mesh crusher of $100 \mathrm{~cm}$ and $200 \mathrm{~cm}$ using drill hole $105 \mathrm{~mm}$, Mariz et al (2019) predict that $80 \%$ and $99.90 \%$ respectively of passers in mesh crusher of $85.6 \mathrm{~cm}$ and $200 \mathrm{~cm}$ using drill hole $88.9 \mathrm{~mm}$, Shaib et al (2020) predict $100 \%$ of passers in mesh crusher of $100 \mathrm{~cm}$ using drill hole $76 \mathrm{~mm}$ and, Agyei et al (2019) and Ninepence et al (2016) predict respectively 96.6\% passers in mesh crusher of 300 $\mathrm{cm}$ using drill hole $115 \mathrm{~mm}$ and $80 \%$ passing within the optimum size range of $100 \mathrm{~cm}$ using drill hole $165 \mathrm{~mm}$. Bidzar's model is reliable with $100 \%$ of the blocks passing through the $250 \mathrm{~cm}$ mesh crusher (Fig.7 to 9) because, according to Agyei et al (2019), all prediction models produce similar distribution patterns with more than $90 \%$ of the blocks passing through the $300 \mathrm{~cm}$ mesh crusher. 


\section{CONCLUSION}

The aim of this work was to predict the fragmentation of the Bidzar marble considering the effect of natural discontinuities and mechanical properties using the Kuz-Ram method, while enhancing the information on the said quarry. The prediction test was carried out with several different steering, dipping and compressive strength shots existing in the quarry. The influence of natural discontinuities and mechanical characteristics on the fragmentation of the marble was thus studied. The following conclusions can be drawn:

(1) The knowledge of the fracturing of quarries and mines allows the detection of existing discontinuity planes. Among these plans of discontinuities, some can be used as firing plans. These are mainly firing planes with difficult to very difficult drawability and with dips between $60^{\circ}$ and $90^{\circ}$ with a $60^{\circ}$ limit. Pullability is an important parameter that determines which discontinuity planes can be used as firing planes. In the same way, fracturing makes it possible to classify the discontinuity planes into families of direction and consequently to identify the favourable zone of the quarry or mine generating the best fragmentation after firing.

(2) Fragmentation is influenced by the dip of the firing planes and not by their direction. Rather, the direction of the firing planes has an impact on the stability and the correct alignment of the front, and helps to minimize the difficulties of felling. Fragmentation intensifies as the dip of the firing planes decreases. The $60^{\circ}$ dip plane is the limit plane that generates optimal fragmentation over the entire extent of the quarry or mine.

(3) Fragmentation is a function of the powder factor, the compressive strength of the shot planes and the drilling mesh. Fragmentation intensifies as the powder factor increases. The powder factor increases with decreasing shot-plane dip and increases with increasing shotplane compressive strength. The firing plane with the maximum powder factor is the optimal plane that generates the best possible fragmentation. The $60^{\circ}$ dip limit plane has the highest powder factor of the firing planes and produces optimum fragmentation. The powder factor is therefore an optimisation parameter and is used to determine the shooting plane that produces the best fragmentation after shooting in the operating area. The compressive strength of the firing planes increases with the decrease in the inclination of the planes. Hard firing shots with compressive strengths greater than $90 \mathrm{MPa}$ produce the best fragmentation. On the other hand, the fragmentation decreases with the increase in the drilling mesh. 
Natural discontinuities and the mechanical properties of the rocks have a significant influence on fragmentation, as do the drilling mesh, the quantity of explosive, the powder factor and the drilling diameter. However, the drilling mesh, amount of explosive, powder factor and drilling diameter are the controllable parameters and represent the most important factors influencing rock fragmentation with a rate of 30-45\% while natural discontinuities and mechanical properties are the less controllable parameters with a lesser influence of $2-5 \%$ on fragmentation.

\section{ACKNOWLEDGEMENTS}

The authors thank the Director of CIMENCAM-FIGUIL, for his field assistance as well as the head of the laboratory for the physical and mechanical tests and the head of quarry service of CIMENCAM-FIGUIL.

The authors would also like to thank all the reviewers for theirs constructives criticism and correction as well as, especially the editor-in-chief, for the publication facilities.

\section{COMPETING INTERESTS}

Authors have declared that no competing interests exist. 


\section{REFERENCES}

Abu Bakar M. Z., Tariq S. M., Hayat M.B., Zahoor M. K., Khan M. U. (2013). Influence of geological discontinuities upon fragmentation by blasting. Pakistan journal of science vol. 65 No. 3, P.414.

Adebayo B., Umeh E.C. (2007). Influence of some rock properties on blasting performanceA case study, Medwell online, journal of engineering and applied science 2(1), P.41-44.

Adebola M.J., Ogbodo Do A., Elijah P.O. (2016). Rock fragmentation prediction using Kuz-Ram Model. Journal of Environment and Earth Science ISSN 2224-3216 (Paper) ISSN 2225-0948 (Online) Vol.6, No.5, Department of minerals and petroleum engineering, school of engineering, Kogi State Polytechnic, Lokoja, Nigeria, P.110-115.

Aftes. (2001). Texte provisoire des recommandations pour une description des massifs rocheux utile à l'étude de la stabilité des ouvrages souterrains, GT1, géologie-géotechnique $(19 / 09 / 01)$.

Agyei G., and Owusu-Tweneboah, M. (2019). A comparative analysis of rock fragmentation using blast prediction results, Ghana mining journal, Vol. 19, No. 1, P. 49-58. Akbari M., Lashkaripour G., Yarahamdi B.A., Ghafoori M. (2015). Blastability evaluation for rock mass fragmentation in Iran central iron ore mines. International journal of mining science and technology 25, P.59-66. http://dx.doi.org/10.1016/j.ijmst.2014.11.008.

Ash R L. (1973). The influence of geological discontinuities on rock blasting, Ph.D. Thesis, University of Missouri Rolla. 87, P.2.

Behrouz O. (2018). Investigation of the influence of heterogeneous and anisotropic nature of rock mass on blast-induced outcomes-a case study at detour lake mine. Master of applied Science Department of civil engineering University of Toronto, P.1-153.

Blair A.C. (2015). A novel powder factor based bench blast design method for large surface coalmines. Doctoral dissertations, Missouri University of science and technology, P.1-22.

Belhous Merzouk. (2016). Elaboration d'un plan de tir pour améliorer la fragmentation des roches -Cas de la carrière d'Ain El Kebira, Université Abderrahmane Mira de Bejaia Faculté de Technologie Département des Mines et géologie, mémoire en vue de l'obtention du Diplôme de master en mines option exploitation minière, P. 23-113. 
Belland J.M. (1968). Structure as a control in rock fragmentation coal lake iron ore deposited,

The Canadian mining and metallurgical bulletin, Vol. 59, 647, P.323-328.

Biessikirski A., Dworzak M.., Twardosz M., Pyra J., Barańsk K. (2019). Comparison analysis of muck pile fragmentation obtained through the photogrammetry method and based on the Kuz-Ram empirical model. Inżynieria Mineralna -Styczeń -Czerwiec (2019) January-June - journal of the Polish mineral engineering society, P.259-261.

Burkle W.C. (1979). Geology and its effect on blasting. Proceedings of the 5th conference on explosives and blasting techniques, SEE, P.105-120.

Cunningham V. B. (1983). The Kuz-Ram model for the prediction of fragmentation from blasting, proceedings of the international symposium on rock fragmentation and blasting, Lulea, August 22-26, P.439-454.

Cunningham C. V. B. (1987). Fragmentation estimations and the Kuz-Ram model-four years on, proceedings of the second international symposium on rock fragmentation by blasting, Keystone, August 23-26, P. 475-487.

Cunningham C.V.B. (2005). The Kuz-Ram model-20 years on. Brighton conference proceedings, P.201-210.

Delille F. (2012). Recherche d'une prédiction de fragmentation charge par charge pour les tirs à ciel ouvert, Ecole des mines de Paris, Thèse de doctorat, P. 7-61.

Devkota, K.C., Kim, G.W., Lee H.N., Ham, J.E. (2009). Characteristics of discontinuity spacing in a rock mass proceedings of the international conference on rock joints and jointed rock masses, Tucson, Arizona, USA, January 7-8, P.1-5.

Djouldi M., Kherbachi H., Mehri D. (1997). Amélioration de la qualité de fragmentation des roches fissurées lors de l'abattage à l'explosif dans les mines à ciel ouvert, Revue française de Géotechnique $N^{\circ} 78$.

Fogelsen D. E., Duvall W I., Atchison T.C. (1958). Strain energy in explosion - Generated strain pulses. U.S. Bureau of Mines, report of Inv.5514.

Gadikor J. (2018). Optimization of drilling and blasting practices at a Western US open pit copper mine. Graduate Theses and Non-Theses. 168, master of science in mining engineering Montana Tech, P.1-14. 
Gaucher F. (2011). Planification des travaux de sautage Excavation par bancs à ciel ouvert d'une carrière de calcaire fossilifère. Goldman Exploration, 860 boul. de la Chaudière Québec, Qc, G1X 4B7Le 31 octobre 2011, P.1-23.

Gheibie S., Aghababaei H., Hoseinie S.H., Pourrahimian Y. (2009). Modified Kuz-Ram fragmentation model and its use at the Sungun copper Mine. International Journal of Rock Mechanics \& Mining Sciences 46 (2009), P.967-973.

Hustrulid W. (1999). Blasting principles for open pit mining. Volume 1, A.A. Balkema Pub., P.382.

Jug J., Stjepan S., Gazdek.M., Kavur.B. (2017). Fragment size distribution of blasted rock mass. World multidisciplinary earth sciences symposium (WMESS 2017) IOP publishing, OP conf. series: Earth and Environmental Science 95 042013, P.1-2.

Kamulete M. (2014). Cours d'exploitation des Mines à ciel ouvert, Université de Lubumbashi, p. 92-135.

Kuznetsov V.M. (1973). The mean diameter of fragments formed by blasting rock. J Min Sci, 9, P.144-148.

Koudou A., Assomat V., Adiaffi B, Youan T., Kouamek F., Lasmt. (2014). Analyses statistique et géostatistique de la fracturation extraite de l'imagerie asar envisat du sud-est de la côte d'ivoire, Université Jean Lorougnon Guédé, Larhyss Journal, p. 147-166.2014.

Langefors U., Kihlstrom B. (1979). The modern technique of rock blasting, AWE / Gebers, Stockholms, Suede, P.438.

Mariz J.L.V., Rocha.S. S., Filinkoski.G., Da Silva.D.M.P.V., De Baros.F.B.M., De Lima.M.P., De Souza.J.S. (2019). analysis of influence of structural geology and geomechanical in the blasting rocks prediction. Technical contribution at the symposium $20^{\circ}$ Mineracao, intern part of Abm week, Brazilia, October 01-03, P. 1-3.

Metftah A. (2010). Méthode de soutènements des écrans de soutènements, chapitre 2.P 3031.

Mohammad B., Mohammad A., Farhang S., Farzad S., Sadjad M. (2018). A new framework for evaluation of rock fragmentation in open pit mines. Faculty of mining engineering, petroleum and geophysics, Shahrood University of technology, Shahrood, Iran. Journal of rock mechanics and geotechnical engineering 11, P.325-336. 
Mulenga S. (2020). Evaluation of factors influencing rock fragmentation by blasting using interrelations diagram method, Capri journal, journal of physical science, ISSN 2520084X(online), University of Zambia, vol 2, issueN¹, P.1-16.

M'zonchem K., Chenafa W. (2006). Etude géotechnique de la stabilité des talus dans la carrière de Ain El Kebira. Mémoire de finn d'étude du diplôme d'ingénieur d'état en géologie, Université de Sétif. P.12-40.

Ndjeng E. (1998). Sedimentary structures of the Babouri-Figuil basin (Bénoué ditch) in North Cameroon. In geoscience of Cameroon as Vicat J. and Bilong P, collect GEOCAM 1/1998, press University. Yaounde I, P.149-156.

Ninepence, J. B, Appianing, E.J.A., Kansake, B.A., Amoako, R. (2016). Optimization of drill and blast parameters using empirical fragmentation modelling, $4^{\text {th }}$ UMaT Biennial international mining and mineral conference, P.25-29.

Ouchterlony F., Sanchidrián J.A. (2019). Review of development of better prediction equations for blast fragmentation. Journal of rock mechanics and geotechnical engineering 11, P. 1094-1109.

Porokhovoï E. (1995). Stabilité à long terme des talus de mines à ciel ouvert dans les massifs de roches basiques et ultrabasiques, Thèse de Doctorat, Ecole nationale des ponts et chaussées en géologie de l'ingénieur, P. 17-24.

Rosin P., Rammler E. (1933). The laws governing the fineness of powdered coal, J. Inst. Fuel, vol. 7, P.29-36.

Rustan. A. (1990). Spacing and borehole diameter at rock blasting, $3^{\text {rd }}$ international symposium on rock fragmentation by blasting, Brisbane, P. 303-310.

Saadoun A. (2012). Contribution à l'analyse des effets des tirs d'abattage dans les conditions de la carrière de calcaire Chouf-Amar. M'sila, mémoire en vue de l'obtention du diplôme de Magister en Mines, Université Badji Mokhtar, p. 66-70.

Sang Ho Cho., Katsuhiko K. (2004). Rock fragmentation control in blasting. The Mining and materials processing institute of Japan, materials transactions, Vol. 45, No. 5, P.17221730.

Shaib A.S., Kudirat O.Y., Hashim M.H.M. (2020). Comparative study of WipFrag image analysis and Kuz-Ram empirical model in granite aggregate quarry and their application for 
blast fragmentation rating, geomechanics and geoengineering, P.1-10. Doi: $\underline{10.1080 / 17486025.2020 .1720830 .}$.

Segaetsho G., Zvarivadza T. (2019). Application of rock mass classification and blastability index for the improvement of wall control: a hard rock mining case study,volume 119, P.1-40. http://dx.doi.org/10.17159/2411-9717/2019/v119n1a4.

Singh, S. (2005). Blast damage control in jointed rock mass. Fragblast, 9(3), P.175-187.

Singh., Narendrula R. (2007). The influence of rock mass quality in controlled blasting $26^{\text {th }}$ international conference on ground control in mining, P.314-319.

Singh P.K., Roy M.P., Paswan R.K., Sarim M.D., Suraj K., Rakesh R.J. (2015). Rock fragmentation control in open cast blasting. Journal of rock mechanics and geotechnical engineering, P.225-237.

Stjepan S., Gazdek M., Mesec J. (2011). Blasting design for obtaining desired fragmentation. technical gazette18, ISSN1330-3651, UDC/UDK 622.235.1'14, P.79-86.

U.S. Bureau of Reclamation. (2001). Engineering geology field manual, chapter, P.210-298.

Wouatong A., Kenmoe O., Ngapgue F., Katte V., and Kamgang V. (2017). A geological and physico - mechanical characterization of marble of the Bidzar quarry North-Cameroon, British journal of applied science and technology, P. 2-7.

Worsey P.N., Farmer I.W., Matheson G.D. (1981). The mechanics of presplitting in discontinuous rock. Proceedings $22^{\text {nd }}$ US rock mechanics symp. University of Missouri Rolla, USA, P.205-210.

Yahyaoui S., A. Hafsaoui A., A. Aissi A., A. Benselhoub A. (2018). Relationship of the discontinuities and the rock blasting results. Dniprop, univer, bulletin, geology, geography, $\mathrm{P}$ 208-218. 


\section{FIGURE CAPTATION}

Figure 1. Location and the geomorphological maps of the study area

Figure 2. Stereographic projection and major direction of discontinuity planes of the Bidzar quarry

Figure 3. Curve of explosive consumption function of the frequency of fractures and shear strength

Figure 4. Percentage of blocks passing in the crusher for blasting planes of dip $86^{\circ}, 70^{\circ}, 85^{\circ}$, $75^{\circ}, 60^{\circ}, 90^{\circ}, 82^{\circ}$ at the mesh $3 \mathrm{~m} \times 3 \mathrm{~m}$

Figure 5. Percentage of blocks passing in the crusher for blasting planes of dip $86^{\circ}, 70^{\circ}, 85^{\circ}$, $75^{\circ}, 60^{\circ}, 90^{\circ}, 82^{\circ}$ at the mesh $4 \mathrm{~m} \times 4 \mathrm{~m}$

Figure 6. Percentage of blocks passing in the crusher for blasting planes of dip $86^{\circ}, 70^{\circ}, 85^{\circ}$, $75^{\circ}, 60^{\circ}, 90^{\circ}, 82^{\circ}$ at the mesh $4.5 \mathrm{~m} \times 4.5 \mathrm{~m}$

Figure 7. Rosin-Rammler distribution curve following the blasting plane of dip $75^{\circ}, 60^{\circ}$, $90^{\circ}, 82^{\circ}$ at mesh $3 \mathrm{~m} \times 3 \mathrm{~m}$

Figure 8. Rosin-Rammler distribution curve following the blasting plane of dip $75^{\circ}, 60^{\circ}, 90^{\circ}$, $82^{\circ}$ at the mesh $4 \mathrm{~m} \times 4 \mathrm{~m}$

Figure 9. Rosin-Rammler distribution curve following the blasting planes of dip $75^{\circ}, 60^{\circ}$, $90^{\circ}, 82^{\circ}$ at the mesh $4.5 \mathrm{~m} \times 4.5 \mathrm{~m}$

\section{Figure 1.}

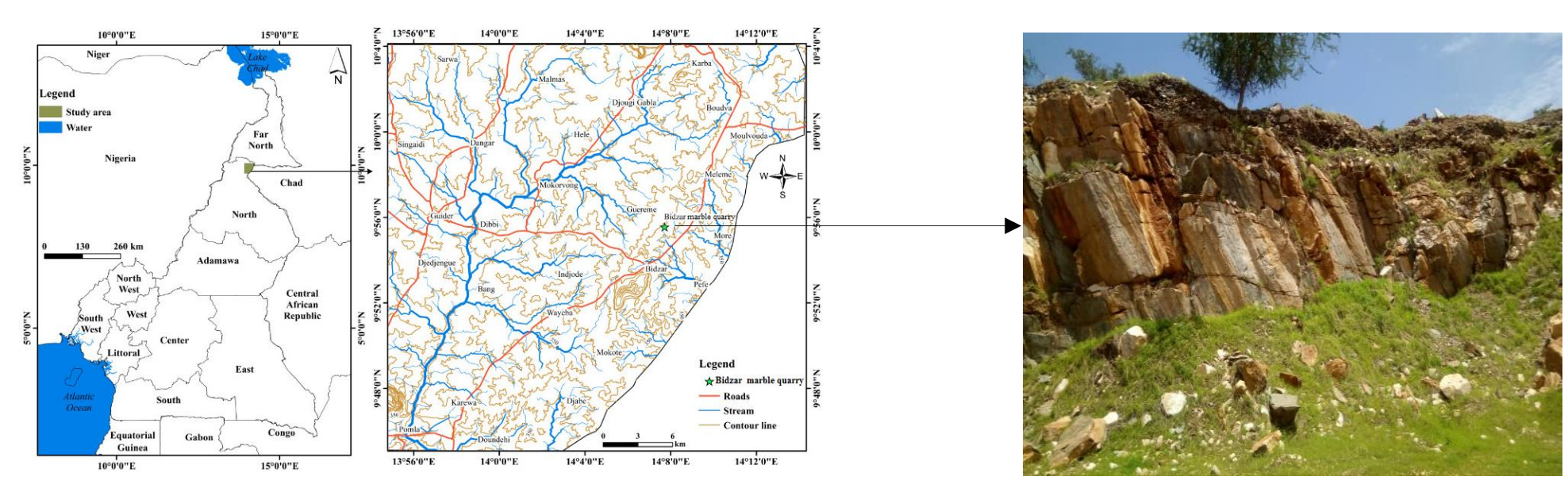


Figure 2.

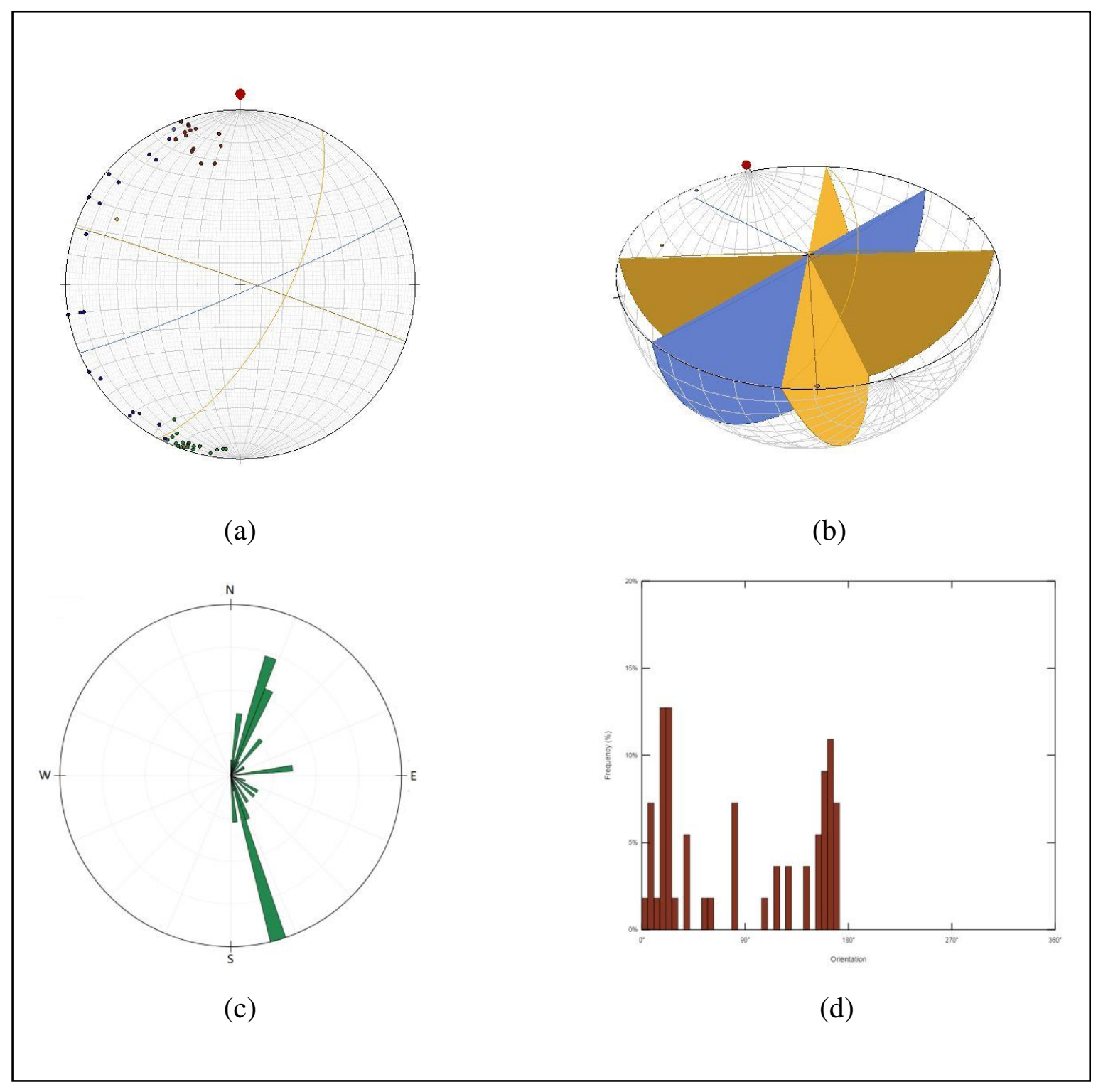


Figure 3.

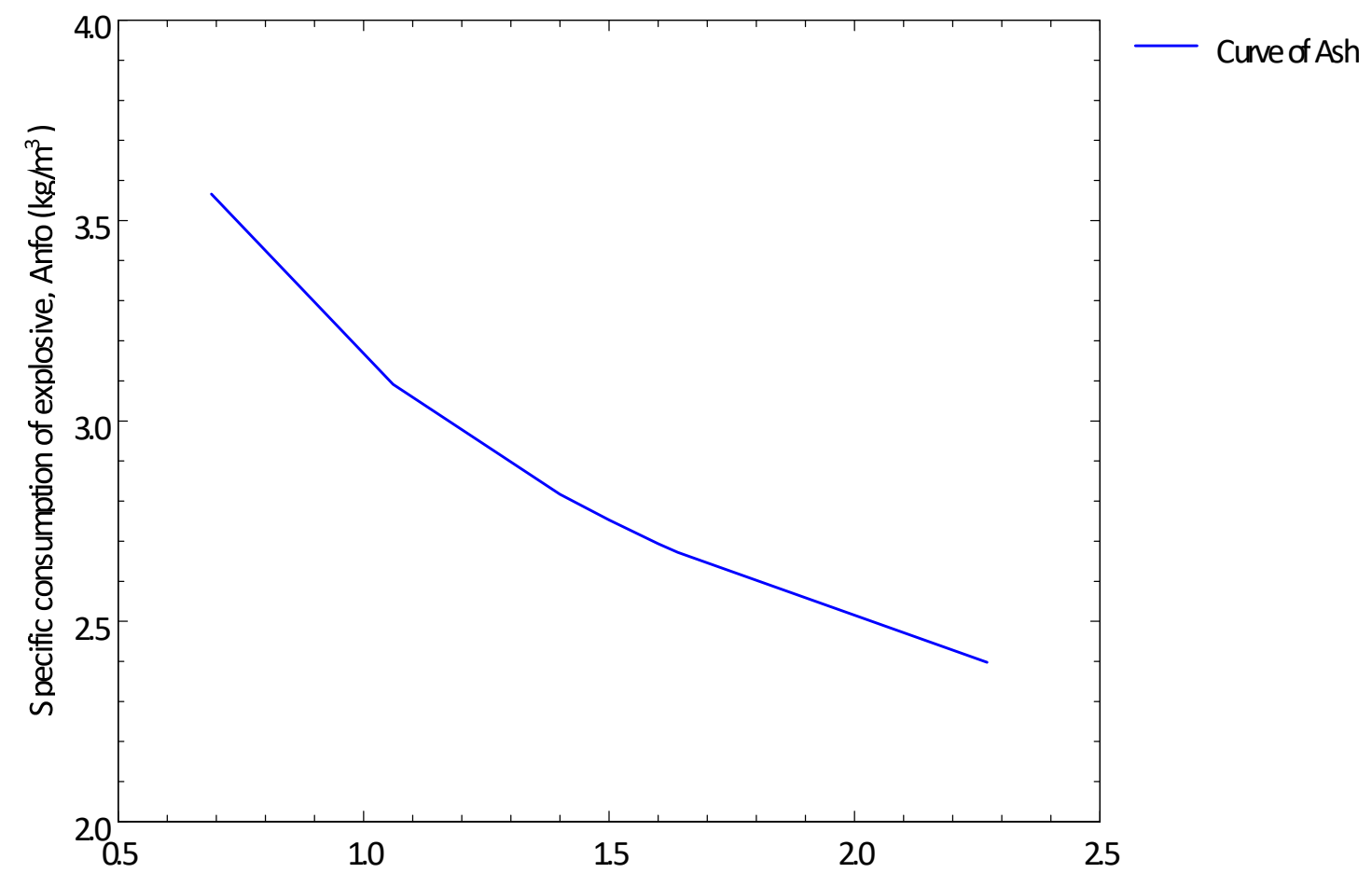

Fracture/meter $\left(\mathrm{m}^{-1}\right)$

\section{Figure 4.}

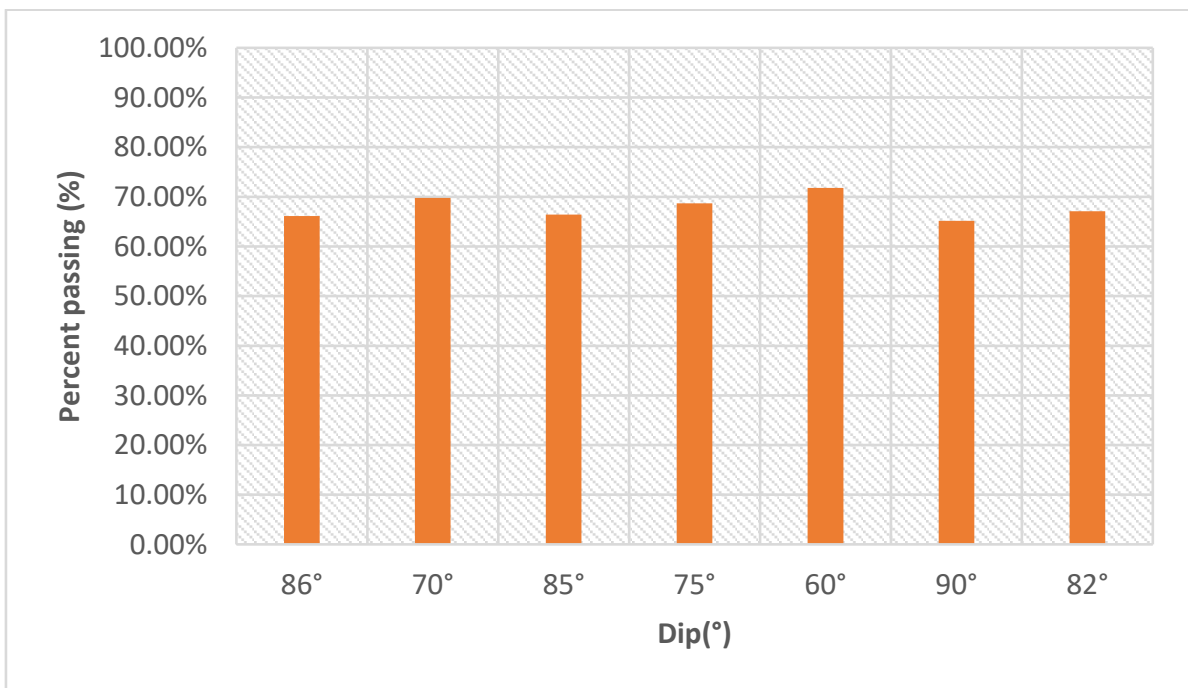




\section{Figure 5.}

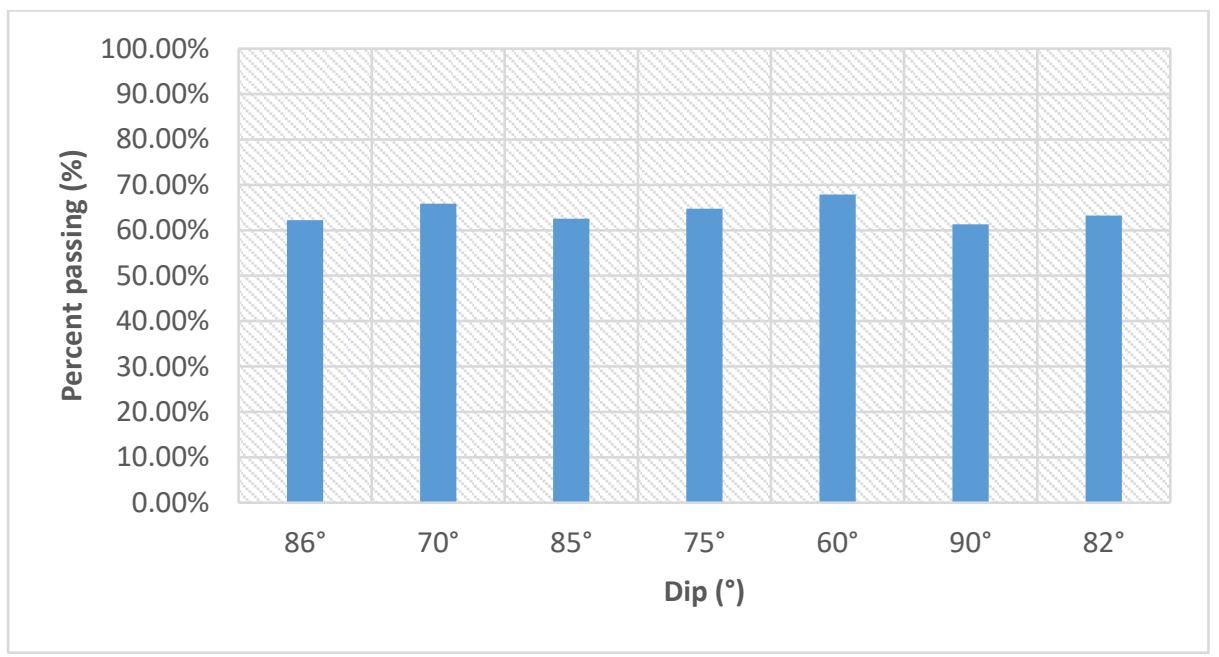

Figure 6.

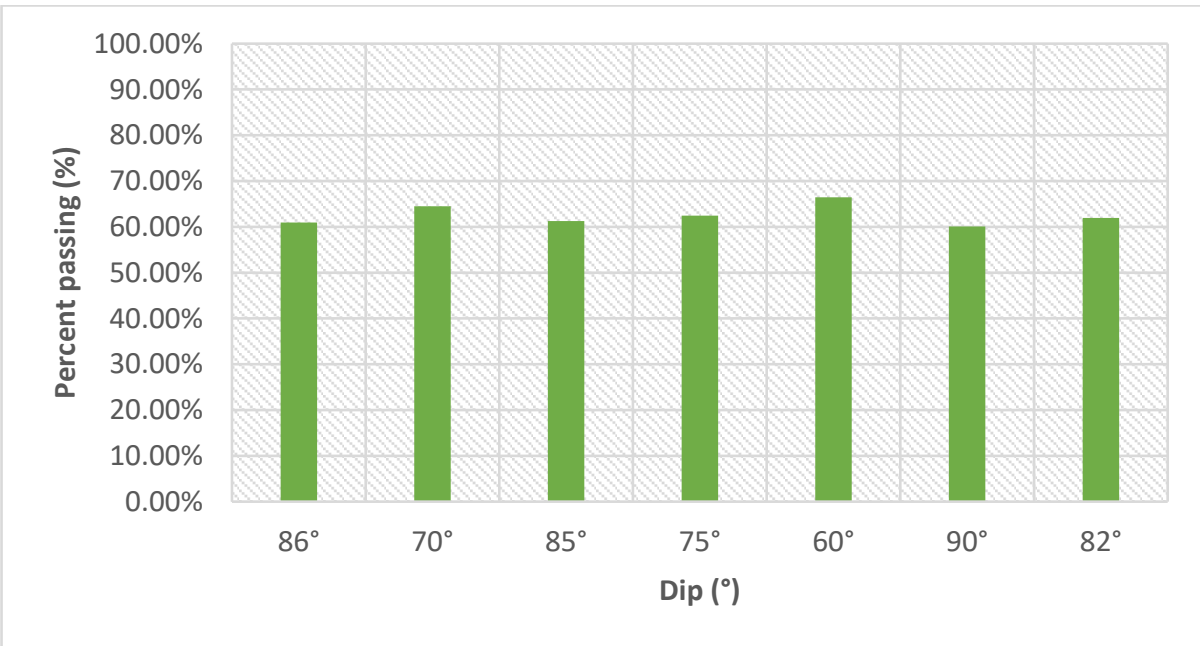


Figure 7.

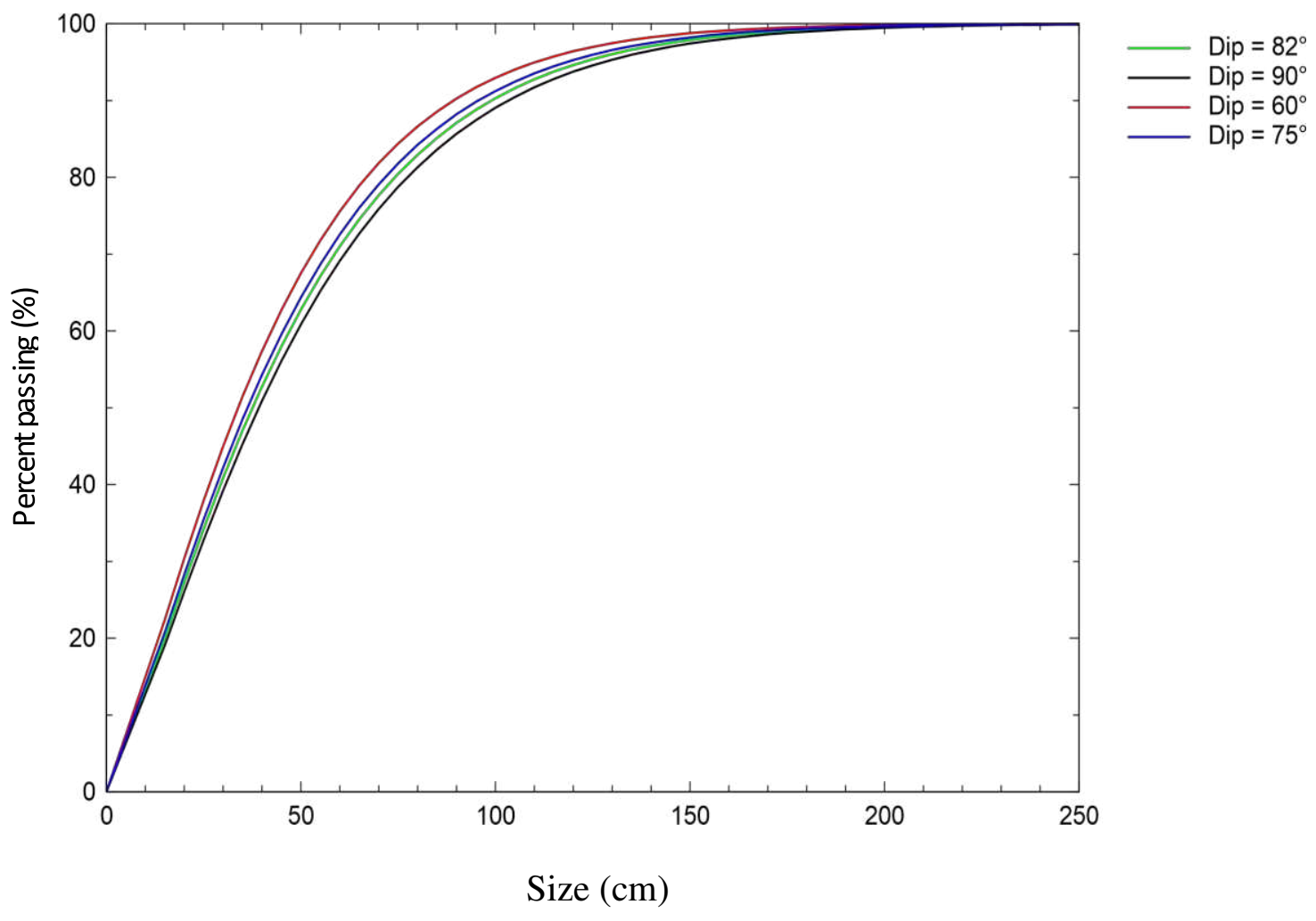

Figure 8.

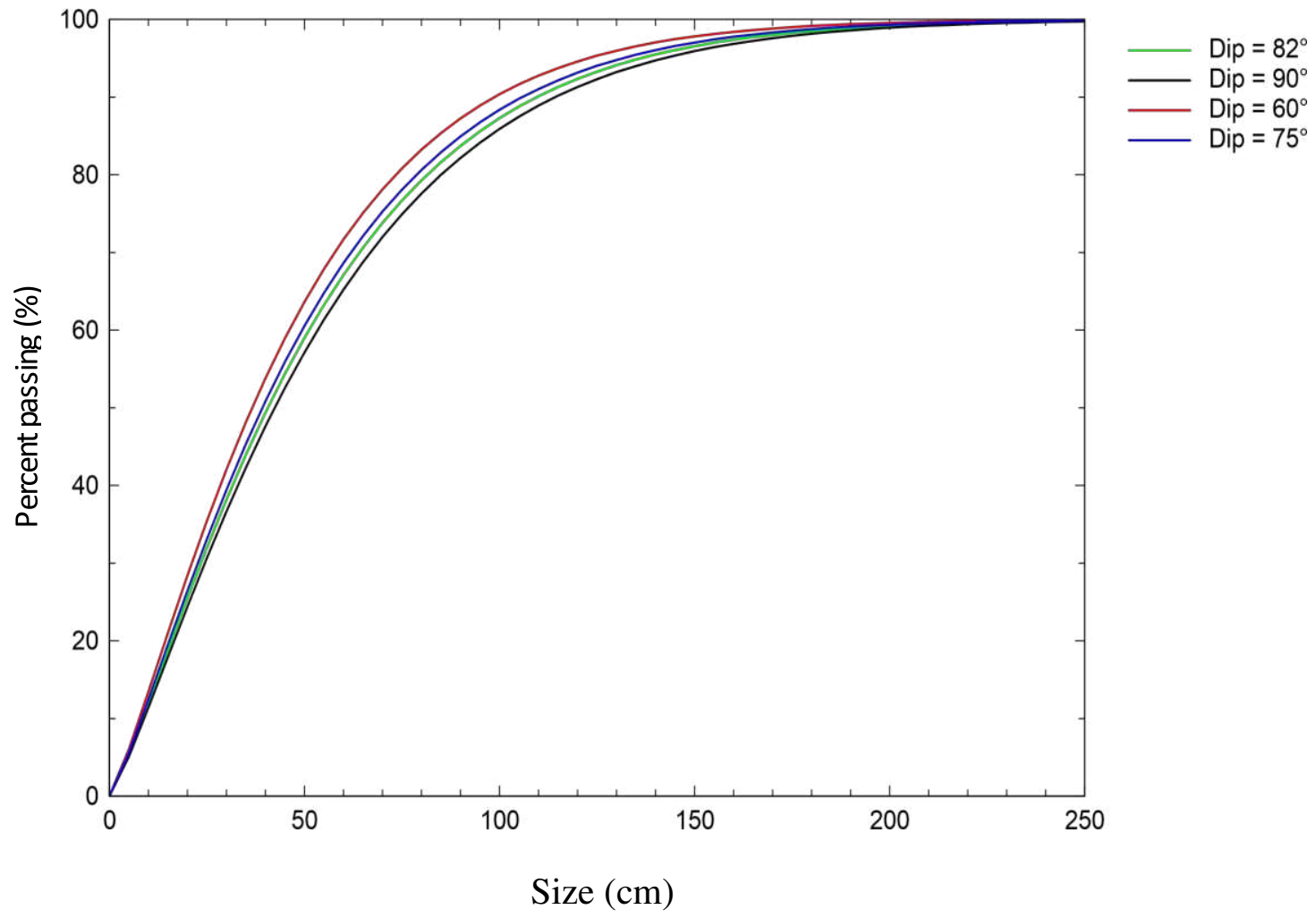


Figure 9.

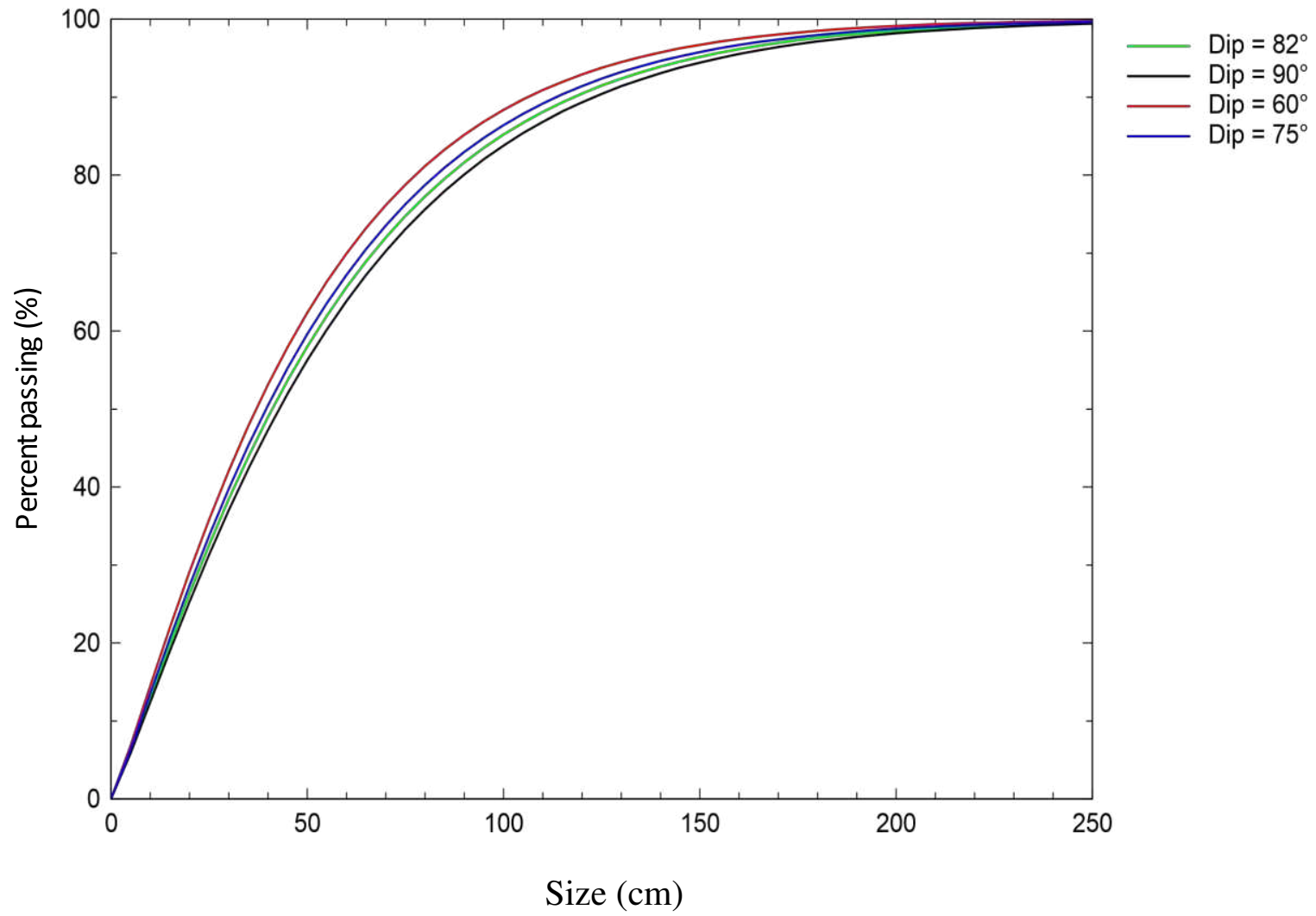




\section{TABLE CAPTATION}

Table 1. Specific consumption of explosive and frequency of fractures

Table 2. Geometric parameters of the discontinuity of Bidzar quarry

Table 3. Rock factor parameters and rates (Mohammad et al, 2019)

Table 5. Parameters of Kuz-Ram model prediction $q_{e t}, k, X / X c, Q, X m, n, X c, P(x)$ with a mesh $3 \mathrm{~m} \times 3 \mathrm{~m}$ according to the dip and compression strength of the blasting planes

Table 6. Parameters of Kuz-Ram model prediction $q_{e t}, k, X / X c, Q, X m, n, X c, P(x)$ with a mesh $4 \mathrm{~m} \times 4 \mathrm{~m}$ according to the dip and compression strength of the blasting planes

Table 7. Parameters of Kuz-Ram model prediction $q_{e t}, k, X / X c, Q, X m, n, X c, P(x)$ with a mesh $4.5 \mathrm{~m} \times 4.5 \mathrm{~m}$ according to the dip and compression strength of the blasting planes

Table 1.

\begin{tabular}{|l|l|l|l|l|l|l|l|l|l|}
\hline Fracture/meter $\left(\mathrm{m}^{-1}\right)$ & 0.69 & 1.06 & 1.4 & 1.4 & 1.5 & 1.5 & 1.6 & 1.64 & 2.27 \\
\hline $\begin{array}{l}\text { Specific consumption of } \\
\text { explosive, Anfo }\left(\mathrm{kg} / \mathrm{m}^{3}\right)\end{array}$ & 3.566 & 3.091 & 2.817 & 2.817 & 2.753 & 2.753 & 2.694 & 2.672 & 2.398 \\
\hline
\end{tabular}

Table 2.

\begin{tabular}{|c|c|c|c|c|c|c|}
\hline Lines & $\begin{array}{l}\text { Position } \\
\text { (m) }\end{array}$ & $\begin{array}{l}\text { Direction/direction } \\
\text { of Reading }\end{array}$ & $\begin{array}{c}\text { Average } \\
\text { space of } \\
\text { discontinuities } \\
(\mathrm{m})\end{array}$ & $\begin{array}{c}\text { Average } \\
\text { frequency of } \\
\text { discontinuities } \\
\left(\mathrm{m}^{-1}\right)\end{array}$ & $\begin{array}{c}\text { Average } \\
\text { space of } \\
\text { fractures } \\
(\mathrm{m})\end{array}$ & $\begin{array}{c}\text { Frequency } \\
\text { of the } \\
\text { fracture } \\
\left(\mathrm{m}^{-1}\right)\end{array}$ \\
\hline L1 & $\begin{array}{c}\mathrm{X} \\
: 0404075 \\
\mathrm{Y}: \\
1098460 \\
\mathrm{Z}: 420\end{array}$ & $\begin{array}{l}\text { N80W } \\
\text { W-E }\end{array}$ & 0.9429 & 1.5 & 0.75 & 1.5 \\
\hline L2 & $\begin{array}{c}\text { X : } \\
0404104 \\
Y:\end{array}$ & $\begin{array}{c}\text { N60W } \\
\text { WNW-ESE }\end{array}$ & 0.7923 & 1.4 & 1.11 & 1 \\
\hline
\end{tabular}




\begin{tabular}{|c|c|c|c|c|c|c|}
\hline & $\begin{array}{c}1098425 \\
Z: 420\end{array}$ & & & & & \\
\hline L3 & $\begin{array}{c}X: \\
0404139 \\
Y: \\
1098411 \\
Z: 426\end{array}$ & $\begin{array}{c}\text { N40E } \\
\text { SW-NE }\end{array}$ & 0.6732 & 1.64 & 0.79 & 1.36 \\
\hline L4 & $\begin{array}{c}X: \\
0404153 \\
Y: \\
1098362 \\
Z: 423\end{array}$ & $\begin{array}{c}\text { N72W } \\
\text { WSW-ENE }\end{array}$ & 1.0565 & 1.06 & 1.64 & 0.67 \\
\hline L5 & $\begin{array}{c}\mathrm{X}: \\
0404165 \\
\mathrm{Y}: \\
1098305 \\
\mathrm{Z}: 425\end{array}$ & $\begin{array}{l}\text { N80E } \\
\text { W-E }\end{array}$ & 0.7348 & 1.5 & 1.17 & 0.93 \\
\hline L6 & $\begin{array}{c}\mathrm{X}: \\
0404144 \\
\mathrm{Y}: \\
1097822 \\
\mathrm{Z}: 457\end{array}$ & $\begin{array}{l}\text { N90W } \\
\text { W-E }\end{array}$ & 1.64 & 0.69 & 0.7 & 0.13 \\
\hline L7 & $\begin{array}{c}\mathrm{X}: \\
0404215 \\
\mathrm{Y}: \\
109784 \\
\mathrm{Z}: 439\end{array}$ & $\begin{array}{l}\text { N90E } \\
\text { W-E }\end{array}$ & 0.4080 & 2.64 & 0.52 & 2 \\
\hline L8 & $\begin{array}{c}\mathrm{X}: \\
04042173 \\
\mathrm{Y}: \\
1097932 \\
\mathrm{Z}: 432\end{array}$ & $\begin{array}{l}\text { N80E } \\
\text { E-W }\end{array}$ & 0.8488 & 1.4 & 1.25 & 0.87 \\
\hline L9 & $\begin{array}{c}\text { : } \\
0404270\end{array}$ & $\begin{array}{c}\text { N16E } \\
\text { SSW-NNE }\end{array}$ & 0.5027 & 2,09 & 1,83 & 0,64 \\
\hline
\end{tabular}




\begin{tabular}{|c|c|c|c|c|c|c|}
\hline & $\begin{array}{c}\mathrm{Y}: \\
1097984 \\
Z: 432\end{array}$ & & & & & \\
\hline L10 & $\begin{array}{c}X: \\
0404270 \\
Y: \\
1097972 \\
Z: 440\end{array}$ & $\begin{array}{c}\text { N60W } \\
\text { WNW-ESE }\end{array}$ & 0.4702 & 2.27 & 0.92 & 1018 \\
\hline L11 & $\begin{array}{c}\mathrm{X}: \\
0404239 \\
\mathrm{Y}: \\
1097817 \\
\mathrm{Z}: 428\end{array}$ & $\begin{array}{l}\text { N140W } \\
\text { NE-SW }\end{array}$ & 0.7888 & 1.42 & 1.2 & 0.92 \\
\hline
\end{tabular}

Table 3.

\begin{tabular}{|c|c|c|}
\hline Parameters & Sub-category & Rating \\
\hline \multirow{3}{*}{$\begin{array}{c}\text { Rock mass } \\
\text { description (RMD) }\end{array}$} & Powdery & 10 \\
\hline & $\begin{array}{l}\text { Vertically } \\
\text { jointed }\end{array}$ & 20 \\
\hline & Massive & 50 \\
\hline \multirow{4}{*}{$\begin{array}{c}\text { Joint plane spacing } \\
\text { (JPS) }\end{array}$} & $<0.1 \mathrm{~m}$ & 10 \\
\hline & $\begin{array}{l}0.1 \mathrm{~m} \text { to } \\
\text { oversize }\end{array}$ & 20 \\
\hline & $\begin{array}{l}\text { Oversize to } \\
\text { Pattern size }\end{array}$ & 50 \\
\hline & $\begin{array}{l}\text { Horizontal } \\
\text { dip }\end{array}$ & 10 \\
\hline
\end{tabular}




\begin{tabular}{|c|c|c|}
\hline \multirow{3}{*}{$\begin{array}{c}\text { Joint plane angle } \\
\text { (JPA) }\end{array}$} & $\begin{array}{l}\text { Discontinuity } \\
\text { dip out of } \\
\text { face }\end{array}$ & 20 \\
\hline & $\begin{array}{l}\text { Discontinuity } \\
\text { dip } \\
\text { perpendicular to } \\
\text { face }\end{array}$ & 30 \\
\hline & $\begin{array}{l}\text { Discontinuity } \\
\text { dip into face }\end{array}$ & 40 \\
\hline $\begin{array}{c}\text { Rock density index } \\
\text { (RDI) }\end{array}$ & Density $\left(\mathrm{t} / \mathrm{m}^{3}\right)$ & $25-50$ \\
\hline \multirow[t]{2}{*}{ Hardness factor (HF) } & If $\mathrm{Ym}<50 \mathrm{GPa}$ & $\mathrm{UCS} / 3$ \\
\hline & If $\mathrm{Ym}>50 \mathrm{GPa}$ & $\mathrm{UCS} / 5$ \\
\hline
\end{tabular}

Note: $Y m=$ Youg's modulus, UCS = uniaxial compressive strength 
Table 4.

\begin{tabular}{|c|c|c|c|c|c|c|c|c|c|c|c|}
\hline $\operatorname{Dip}\left({ }^{\circ}\right)$ & $\begin{array}{c}\text { Compression } \\
\text { strength } \\
\text { (Mpa) }\end{array}$ & $\begin{array}{c}\text { Spacing } \\
(\mathrm{m})\end{array}$ & $\begin{array}{c}\text { Burden } \\
\text { (m) }\end{array}$ & $\begin{array}{c}\text { qet } \\
\left(\mathrm{g} / \mathrm{m}^{3}\right)\end{array}$ & $\begin{array}{c}\mathrm{K} \\
\left(\mathrm{kg} / \mathrm{m}^{3}\right)\end{array}$ & $\mathrm{X} / \mathrm{Xc}$ & $\mathrm{Q}(\mathrm{kg})$ & $\mathrm{Xm}(\mathrm{cm})$ & $\mathrm{n}$ & $\mathrm{Xc}(\mathrm{cm})$ & $\mathrm{P}(\mathrm{X}) \%$ \\
\hline $86^{\circ}$ & 74 & 3 & 3 & 26.260 & 0.539 & 1.066 & 48.537 & 32.766 & 1.238 & 51.594 & $66.11 \%$ \\
\hline $70^{\circ}$ & 86.8 & 3 & 3 & 29.844 & 0.612 & 1.155 & 55.161 & 30.217 & 1.238 & 47.581 & $69.77 \%$ \\
\hline $85^{\circ}$ & 75 & 3 & 3 & 26.540 & 0.545 & 1.067 & 49.054 & 32.547 & 1.238 & 51.249 & $66.42 \%$ \\
\hline $75^{\circ}$ & 82.8 & 3 & 3 & 28.724 & 0.589 & 1.282 & 53.091 & 30.953 & 1.238 & 48.747 & $68.68 \%$ \\
\hline $60^{\circ}$ & 94.7 & 3 & 3 & 32.056 & 0.658 & 1.209 & 59.25 & 28.88 & 1.238 & 45.475 & $71.78 \%$ \\
\hline $90^{\circ}$ & 71 & 3 & 3 & 25.420 & 0.522 & 1.044 & 46.984 & 33.448 & 1.238 & 52.667 & $65.18 \%$ \\
\hline $82^{\circ}$ & 72.6 & 3 & 3 & 27.184 & 0.558 & 1.089 & 50.245 & 32.057 & 1.238 & 50.477 & $67.11 \%$ \\
\hline
\end{tabular}

Table 5.

\begin{tabular}{|c|c|c|c|c|c|c|c|c|c|c|c|}
\hline Dip ( $\left.{ }^{\circ}\right)$ & $\begin{array}{c}\text { Compression } \\
\text { Strength } \\
(\text { Mpa) }\end{array}$ \\
& & $\begin{array}{c}\text { Spacing } \\
(\mathrm{m})\end{array}$ & $\begin{array}{c}\text { Burden } \\
(\mathrm{m})\end{array}$ & $\begin{array}{c}\mathrm{qet} \\
\left(\mathrm{g} / \mathrm{m}^{3}\right)\end{array}$ & $\begin{array}{c}\mathrm{K} \\
\left(\mathrm{kg} / \mathrm{m}^{3}\right)\end{array}$ & $\mathrm{X} / \mathrm{Xc}$ & $\mathrm{Q}(\mathrm{kg})$ & $\mathrm{Xm}(\mathrm{cm})$ & $\mathrm{n}$ & $\mathrm{Xc}(\mathrm{cm})$ & $\mathrm{P}(\mathrm{X}) \%$ \\
\hline $86^{\circ}$ & 74 & 4 & 4 & 26.260 & 0.539 & 0.978 & 86.288 & 36.071 & 1.209 & 56.197 & $62.25 \%$ \\
\hline $70^{\circ}$ & 86.8 & 4 & 4 & 29.844 & 0.612 & 1.061 & 98.065 & 33.265 & 1.209 & 51.825 & $65.82 \%$ \\
\hline $85^{\circ}$ & 75 & 4 & 4 & 26.540 & 0.545 & 0.985 & 87.208 & 35.86 & 1.209 & 55.821 & $62.55 \%$ \\
\hline $75^{\circ}$ & 82.8 & 4 & 4 & 28.724 & 0.589 & 1.035 & 94.385 & 34.08 & 1.209 & 53.095 & $64.77 \%$ \\
\hline $60^{\circ}$ & 94.7 & 4 & 4 & 32.056 & 0.658 & 1.110 & 105.333 & 31.793 & 1.209 & 49.532 & $67.85 \%$ \\
\hline $90^{\circ}$ & 71 & 4 & 4 & 25.420 & 0.522 & 0.958 & 83.528 & 36.821 & 1.209 & 57.365 & $61.33 \%$ \\
\hline $82^{\circ}$ & 72.6 & 4 & 4 & 27.184 & 0.558 & 1.000 & 89.324 & 35.29 & 1.209 & 54.980 & $63.62 \%$ \\
\hline
\end{tabular}


Table 6.

\begin{tabular}{|c|c|c|c|c|c|c|c|c|c|c|c|}
\hline Dip ( $\left.{ }^{\circ}\right)$ & $\begin{array}{c}\text { Compression } \\
\text { strength } \\
(\mathrm{Mpa})\end{array}$ & $\begin{array}{c}\text { Spacing } \\
(\mathrm{m})\end{array}$ & $\begin{array}{c}\text { Burden } \\
(\mathrm{m})\end{array}$ & $\begin{array}{c}\text { qet } \\
\left(\mathrm{g} / \mathrm{m}^{3}\right)\end{array}$ & $\begin{array}{c}\mathrm{K} \\
\left(\mathrm{kg} / \mathrm{m}^{3}\right)\end{array}$ & $\mathrm{X} / \mathrm{Xc}$ & $\mathrm{Q}(\mathrm{kg})$ & $\mathrm{Xm}(\mathrm{cm})$ & $\mathrm{n}$ & $\mathrm{Xc}(\mathrm{cm})$ & $\mathrm{P}(\mathrm{X}) \%$ \\
\hline $86^{\circ}$ & 74 & 4.5 & 4.5 & 26.260 & 0.539 & 0.949 & 109.208 & 37.518 & 1.183 & 57.897 & $60.97 \%$ \\
\hline $70^{\circ}$ & 86.8 & 4.5 & 4.5 & 29.844 & 0.612 & 1.030 & 124.113 & 34.6 & 1.183 & 53.393 & $64.50 \%$ \\
\hline $85^{\circ}$ & 75 & 4.5 & 4.5 & 26.540 & 0.545 & 0.956 & 110.373 & 37.267 & 1.183 & 57.510 & $61.27 \%$ \\
\hline $75^{\circ}$ & 82.8 & 4.5 & 4.5 & 28.724 & 0.539 & 1.005 & 119.456 & 35.447 & 1.183 & 54.702 & $62.44 \%$ \\
\hline $60^{\circ}$ & 94.7 & 4.5 & 4.5 & 32.056 & 0.658 & 1.077 & 133.313 & 33.068 & 1.183 & 51.030 & $66.46 \%$ \\
\hline $90^{\circ}$ & 71 & 4.5 & 4.5 & 25.420 & 0.522 & 0.930 & 105.715 & 38.298 & 1.183 & 59.101 & $60.08 \%$ \\
\hline $82^{\circ}$ & 72.6 & 4.5 & 4.5 & 27.184 & 0.558 & 0.970 & 113.051 & 36.706 & 1.183 & 56.644 & $61.93 \%$ \\
\hline
\end{tabular}




\section{Figures}
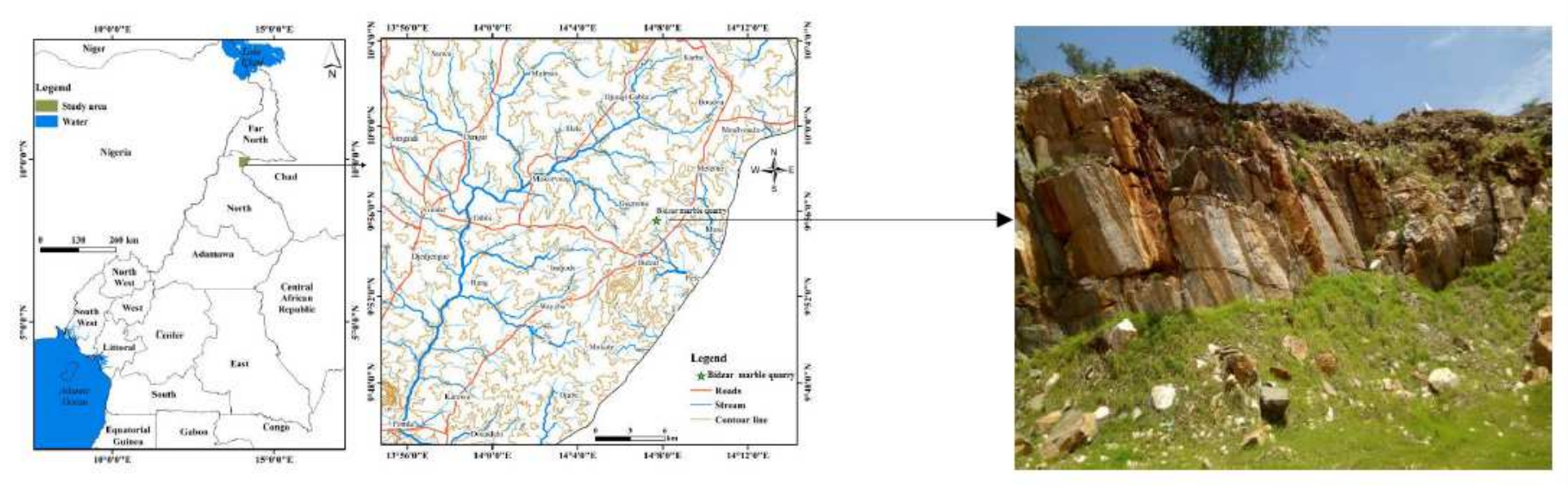

Figure 1

Location and the geomorphological maps of the study area. Note: The designations employed and the presentation of the material on this map do not imply the expression of any opinion whatsoever on the part of Research Square concerning the legal status of any country, territory, city or area or of its authorities, or concerning the delimitation of its frontiers or boundaries. This map has been provided by the authors. 


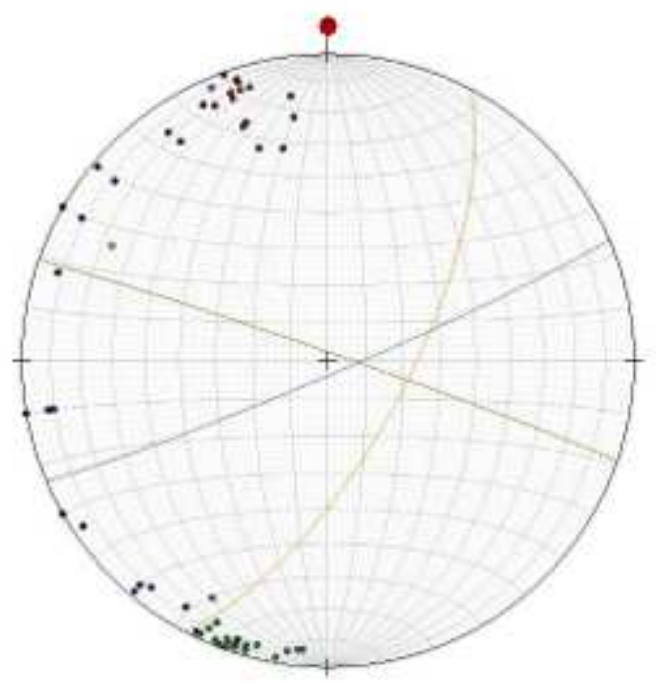

(a)

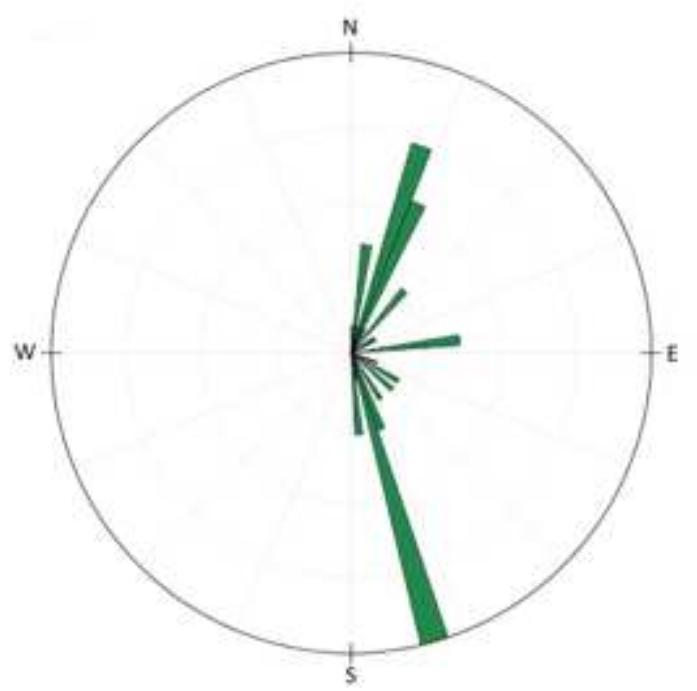

(c)

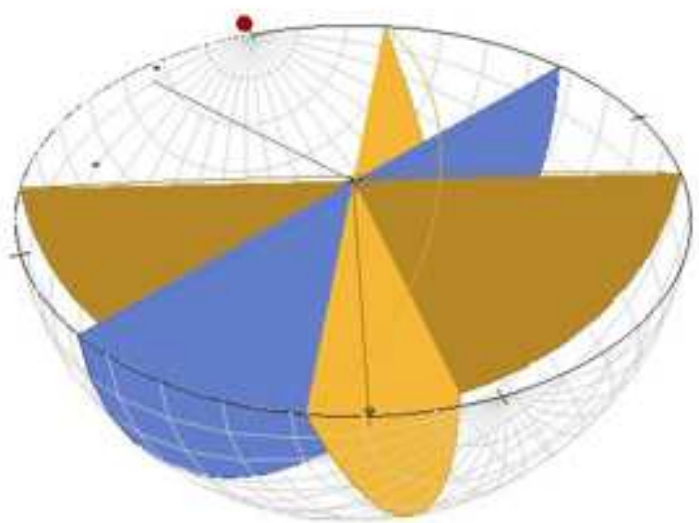

(b)

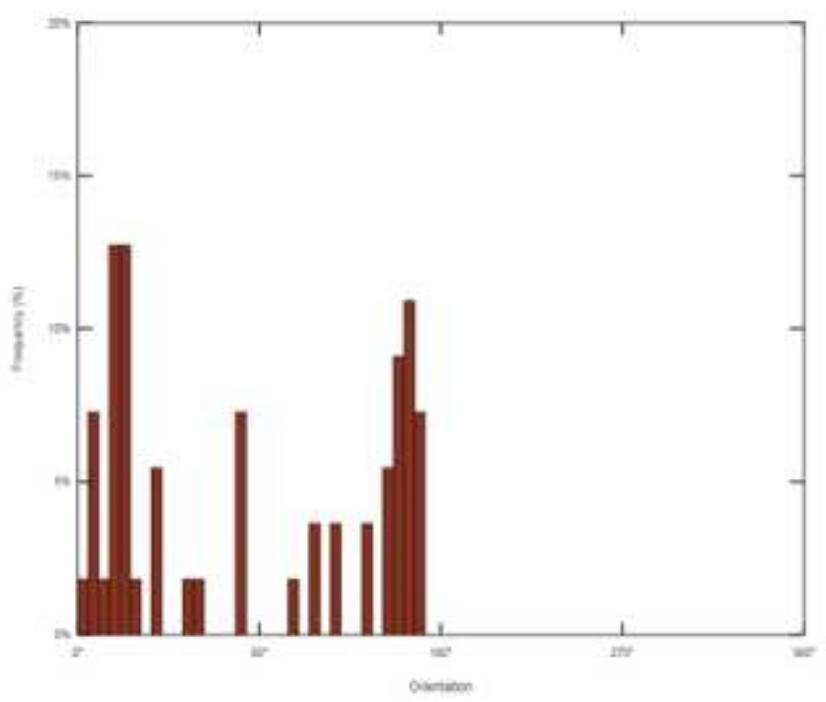

(d)

Figure 2

Stereographic projection and major direction of discontinuity planes of the Bidzar quarry 


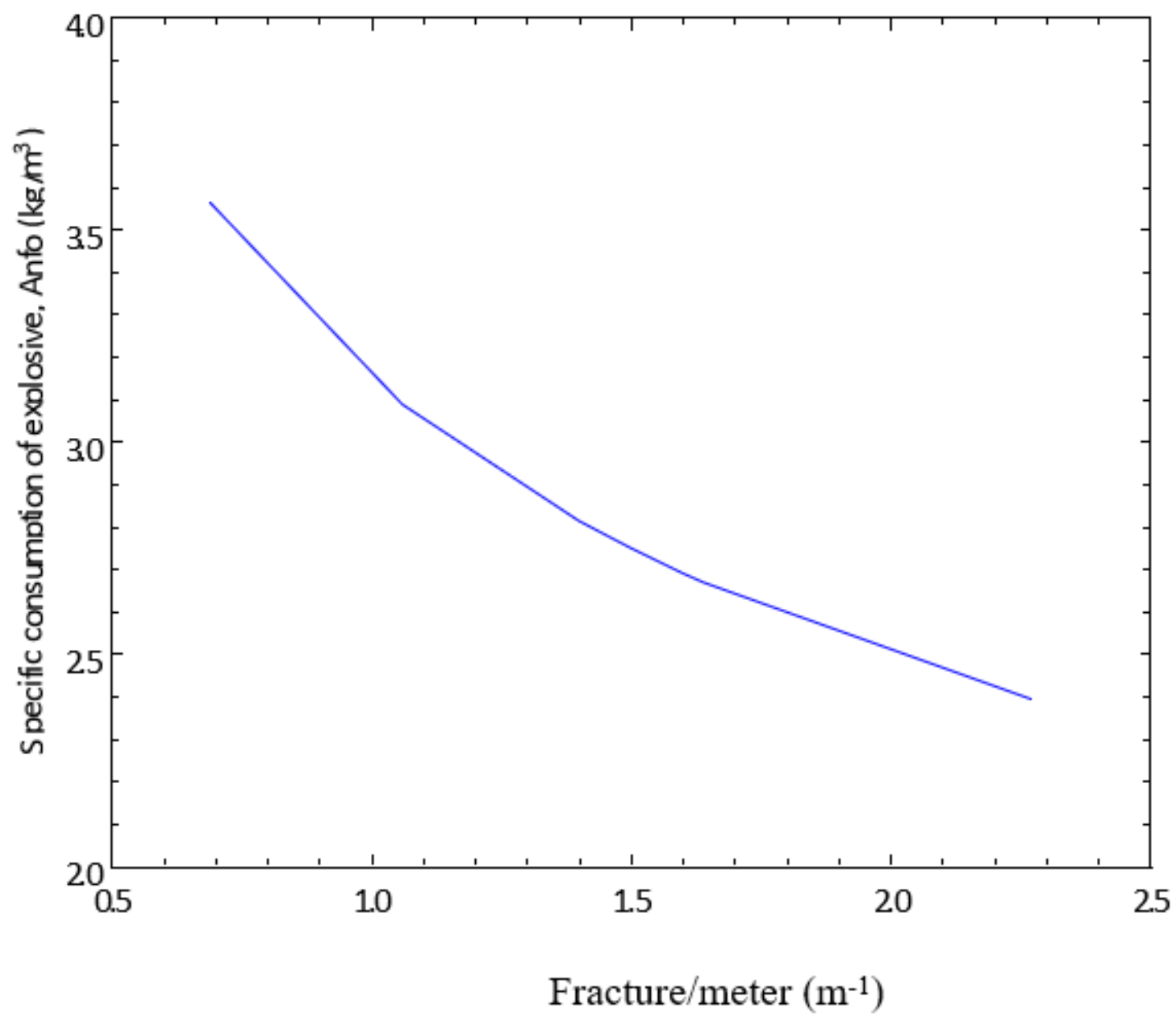

Curve of Ash

Figure 3

Curve of explosive consumption function of the frequency of fractures and shear strength

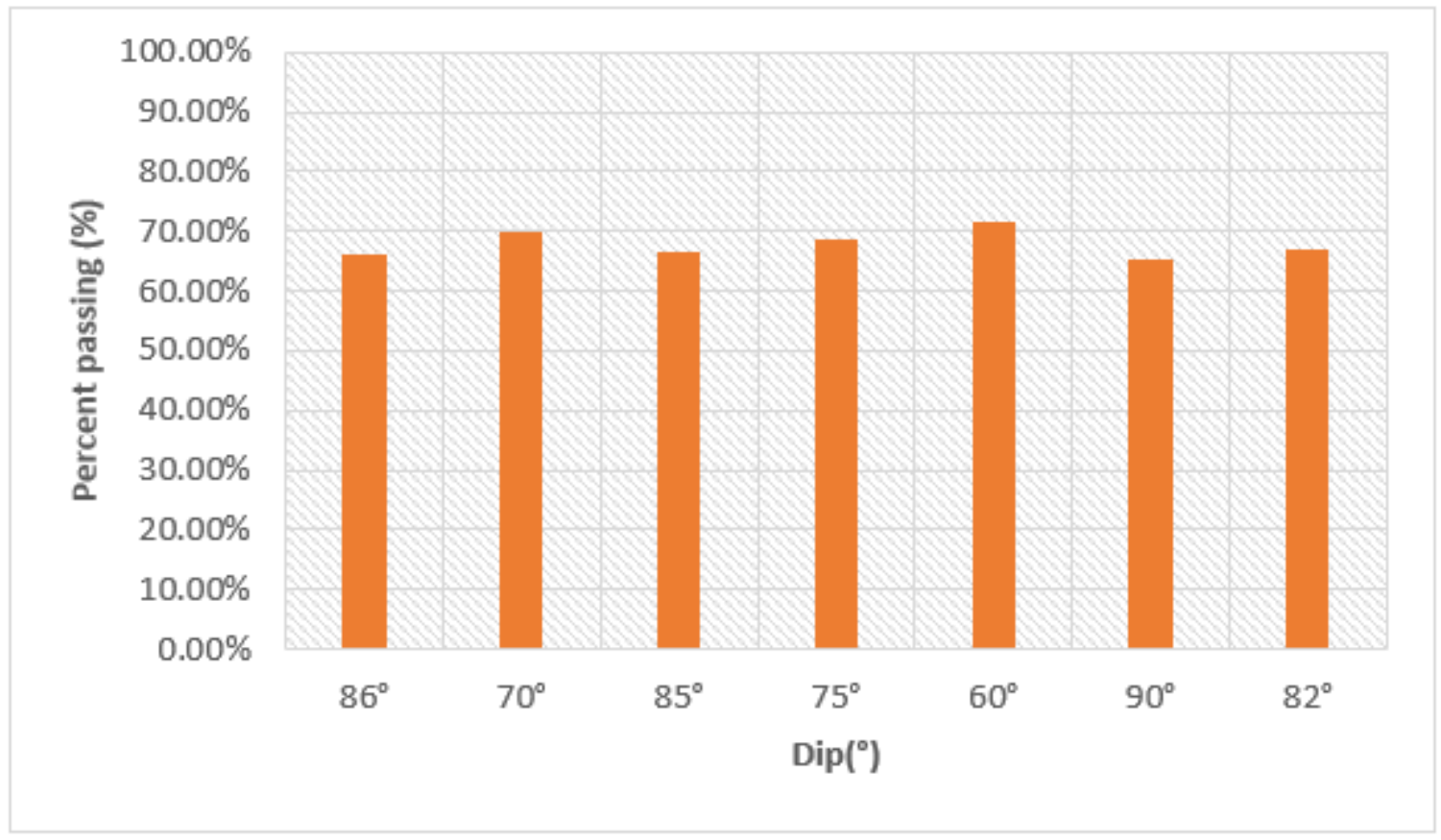


Figure 4

Percentage of blocks passing in the crusher for blasting planes of dip $86^{\circ}, 70^{\circ}, 85^{\circ}, 75^{\circ}, 60^{\circ}, 90^{\circ}, 82^{\circ}$ at the mesh $3 \mathrm{~m} \times 3 \mathrm{~m}$

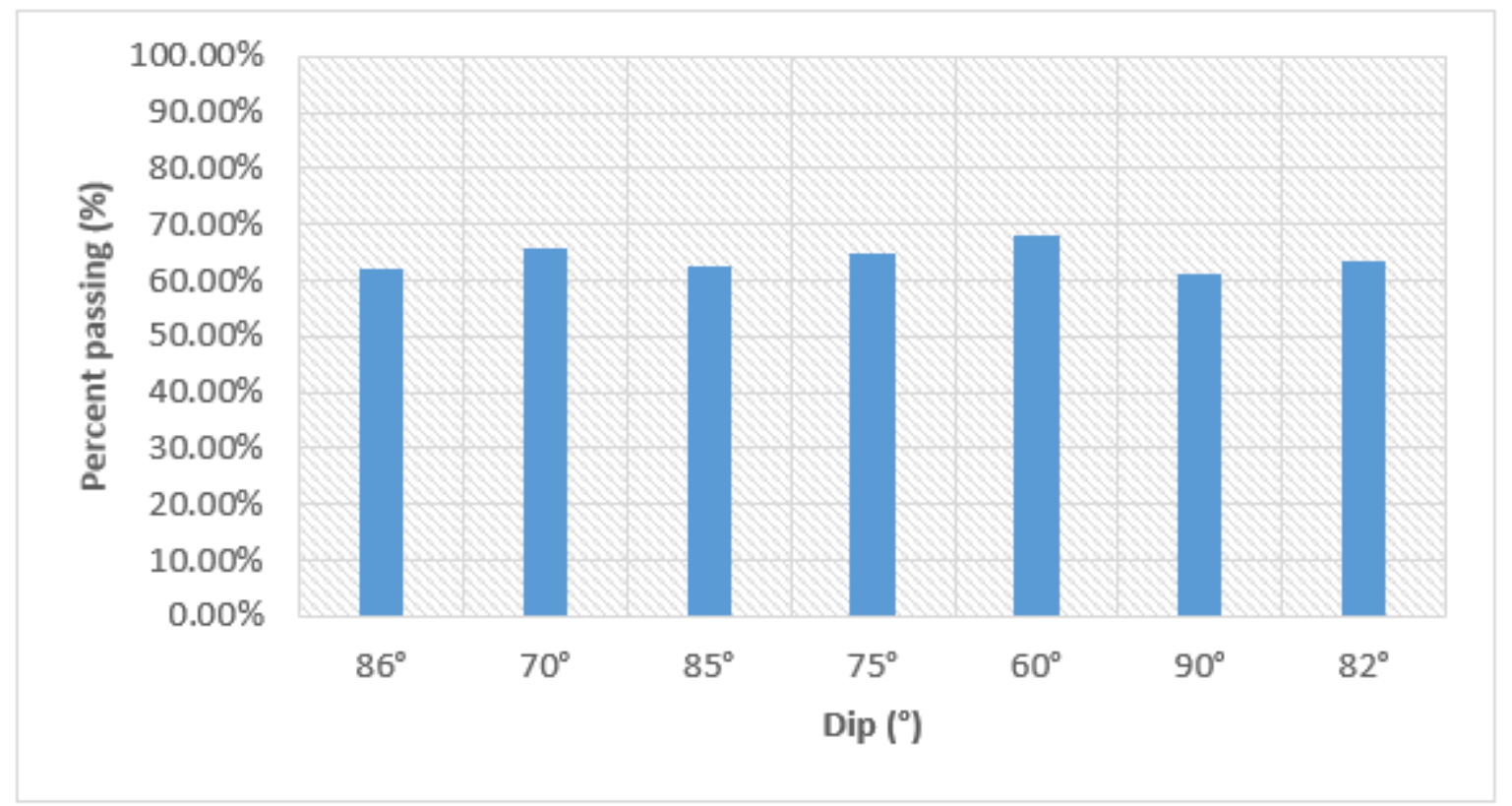

Figure 5

Percentage of blocks passing in the crusher for blasting planes of dip $86^{\circ}, 70^{\circ}, 85^{\circ}, 75^{\circ}, 60^{\circ}, 90^{\circ}, 82^{\circ}$ at the mesh $4 \mathrm{~m} \times 4 \mathrm{~m}$

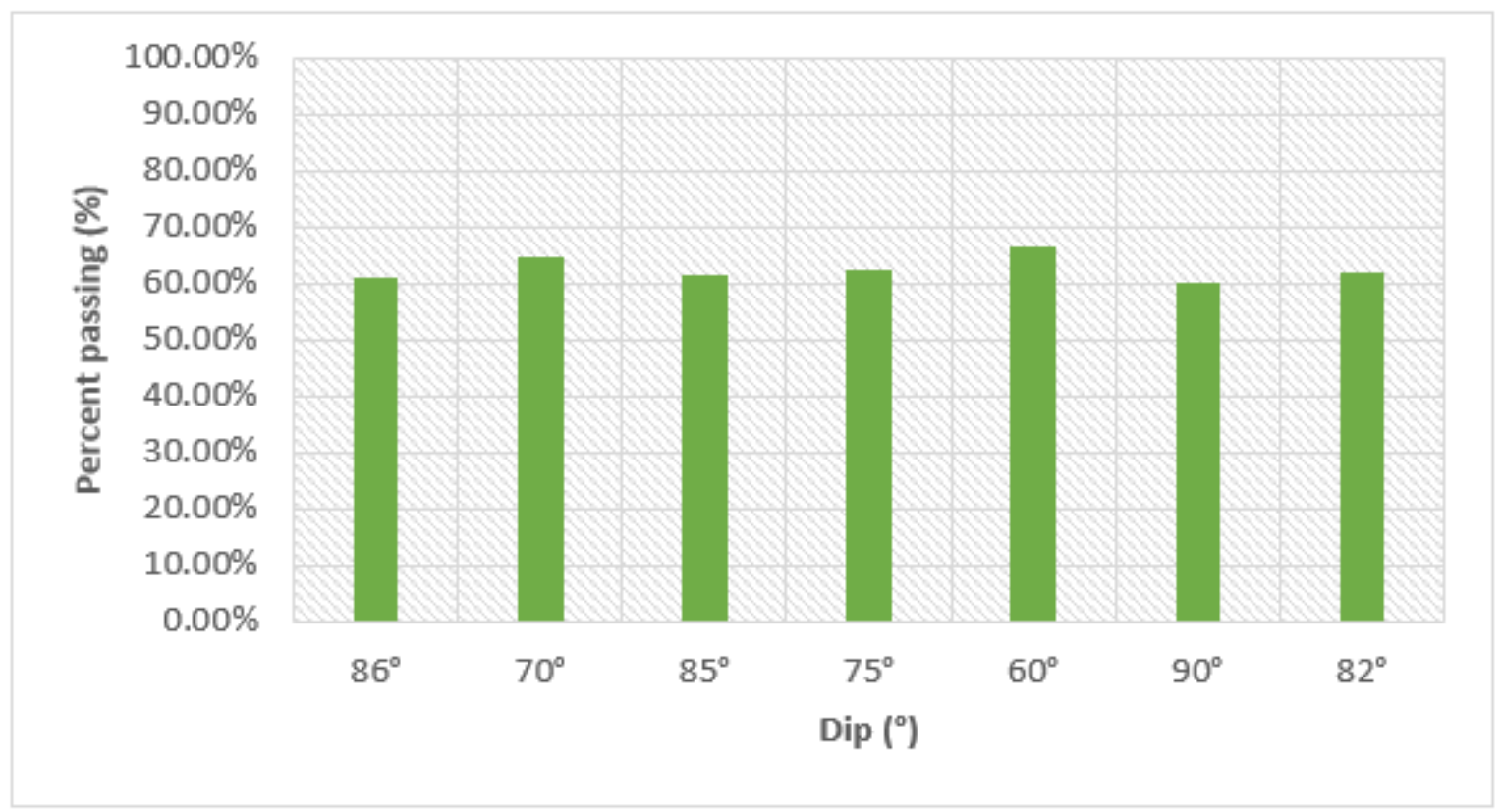

Figure 6 
Percentage of blocks passing in the crusher for blasting planes of dip $86^{\circ}, 70^{\circ}, 85^{\circ}, 75^{\circ}, 60^{\circ}, 90^{\circ}, 82^{\circ}$ at the mesh $4.5 \mathrm{~m} \times 4.5 \mathrm{~m}$

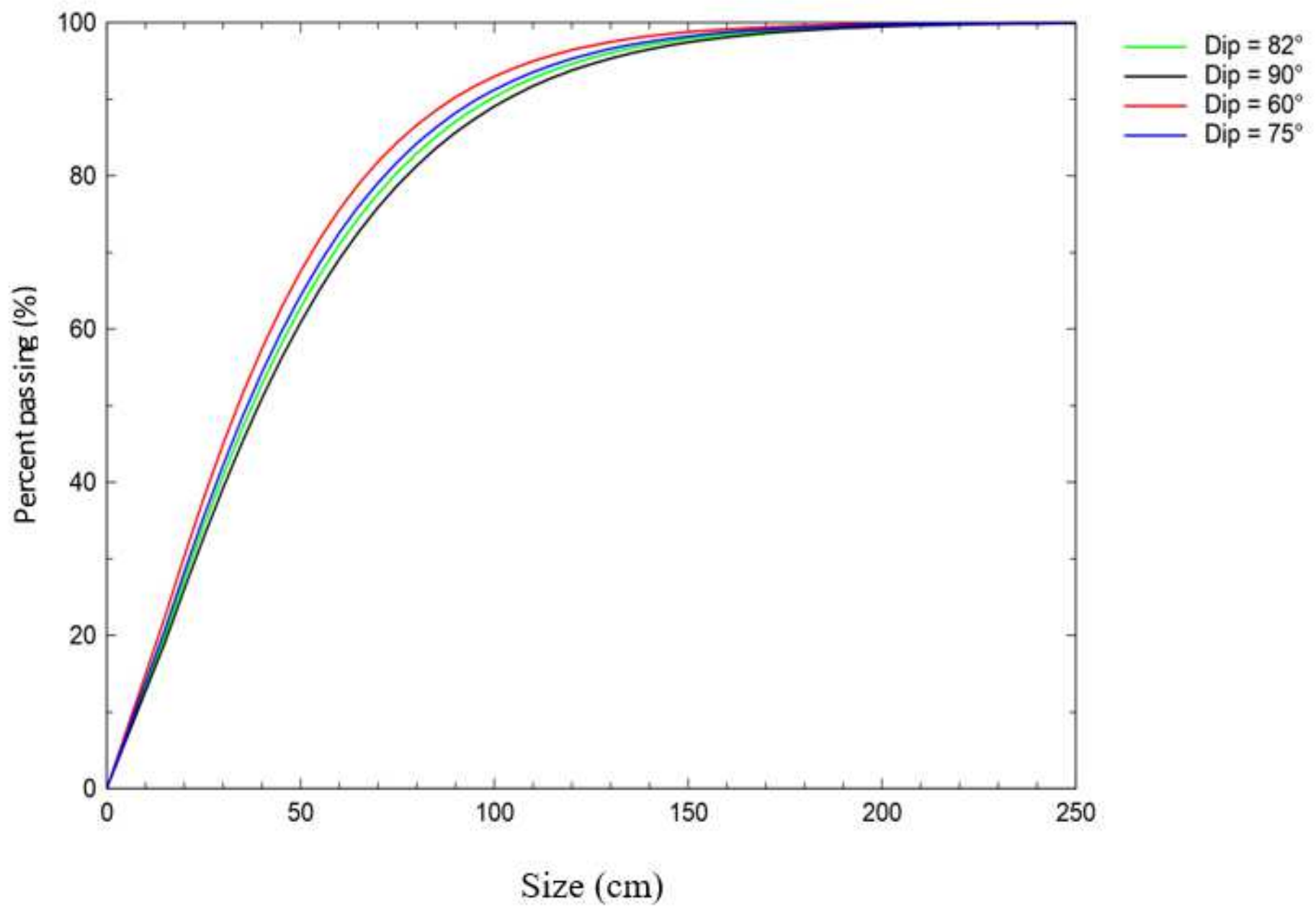

Figure 7

Rosin-Rammler distribution curve following the blasting plane of dip $75^{\circ}, 60^{\circ}, 90^{\circ}, 82^{\circ}$ at mesh $3 \mathrm{~m} \times 3 \mathrm{~m}$ 


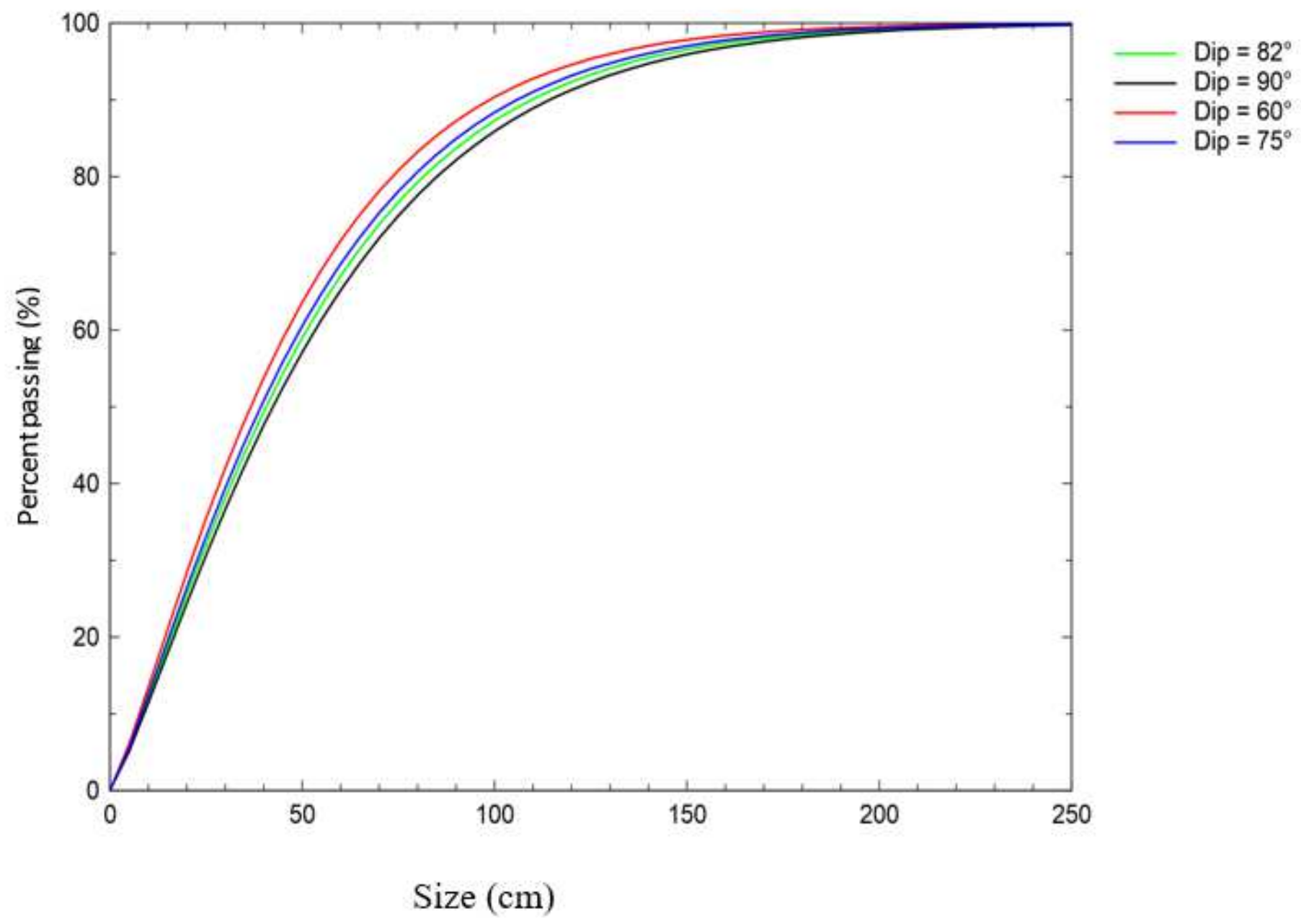

Figure 8

Rosin-Rammler distribution curve following the blasting plane of dip $75^{\circ}, 60^{\circ}, 90^{\circ}, 82^{\circ}$ at the mesh $4 \mathrm{~m} \times$ $4 \mathrm{~m}$ 


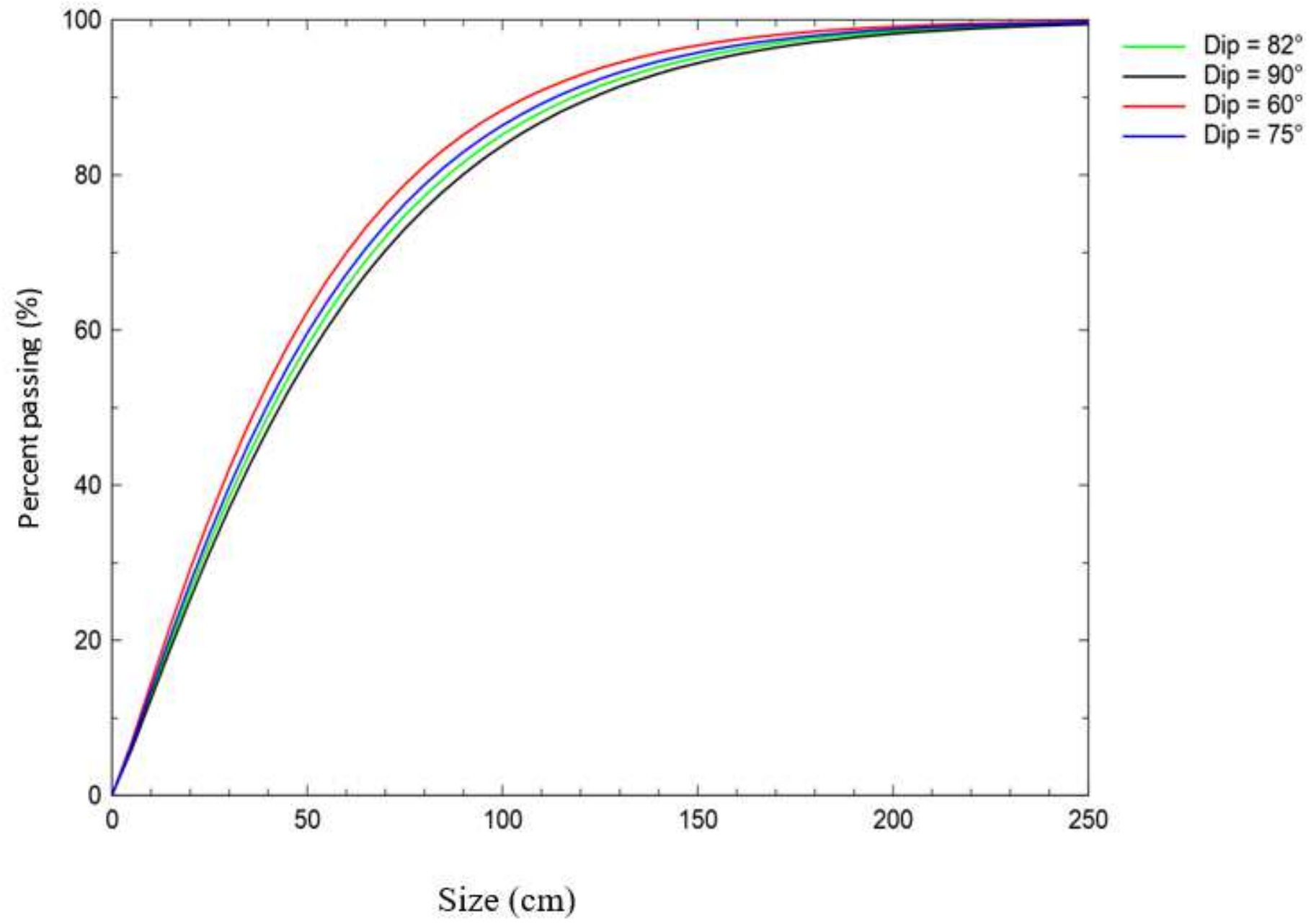

Figure 9

Rosin-Rammler distribution curve following the blasting planes of dip $75^{\circ}, 60^{\circ}, 90^{\circ}, 82^{\circ}$ at the mesh $4.5 \mathrm{~m}$ $\times 4.5 \mathrm{~m}$ 